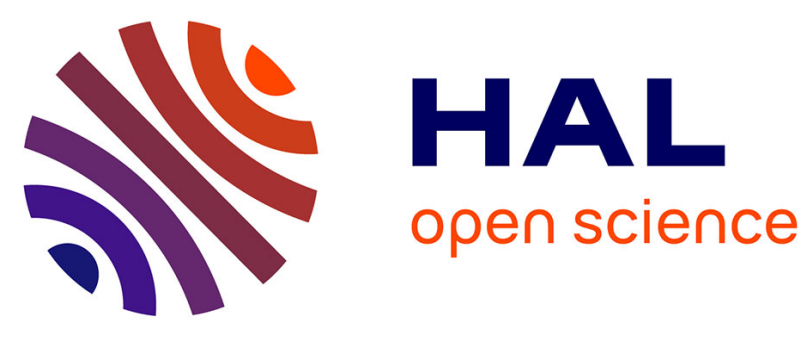

\title{
Potent Lys Patch-containing Stapled Peptides Targeting PCSK9
}

Kévin Bourbiaux, Baptiste Legrand, Pascal Verdié, Sergio Mallart, Géraldine

Manette, Claire Minoletti, J. David David Stepp, Philippe Prigent, Jean-Christophe Le Bail, Laurence Gauzy-Lazo, et al.

\section{To cite this version:}

Kévin Bourbiaux, Baptiste Legrand, Pascal Verdié, Sergio Mallart, Géraldine Manette, et al.. Potent Lys Patch-containing Stapled Peptides Targeting PCSK9. Journal of Medicinal Chemistry, 2021, 64 (15), pp.10834-10848. 10.1021/acs.jmedchem.0c02051 . hal-03371411

\author{
HAL Id: hal-03371411 \\ https://hal.science/hal-03371411
}

Submitted on 8 Oct 2021

HAL is a multi-disciplinary open access archive for the deposit and dissemination of scientific research documents, whether they are published or not. The documents may come from teaching and research institutions in France or abroad, or from public or private research centers.
L'archive ouverte pluridisciplinaire $\mathbf{H A L}$, est destinée au dépôt et à la diffusion de documents scientifiques de niveau recherche, publiés ou non, émanant des établissements d'enseignement et de recherche français ou étrangers, des laboratoires publics ou privés. 


\section{Potent Lys Patch-containing Stapled Peptides}

\section{Targeting PCSK9}

Kévin Bourbiaux $,{ }^{\xi},{ }^{\dagger}$ Baptiste Legrand, ${ }^{*}$ \& Pascal Verdié, ${ }^{\S}$ Sergio Mallart, ${ }^{* \dagger}$ Géraldine Manette, ${ }^{\dagger}$ Claire Minoletti, ${ }^{\dagger}$ J. David Stepp,,$^{\perp}$ Philippe Prigent,$^{\dagger}$ Jean-Christophe Le Bail,${ }^{\dagger}$ Laurence Gauzy-Lazo, ${ }^{\dagger}$ Olivier Duclos, ${ }^{\dagger}$ Jean Martinez ${ }^{\S}$ Muriel Amblard, $* \S$

§ IBMM, Univ Montpellier, CNRS, ENSCM, 34093 Montpellier cedex, France

${ }^{\dagger}$ Sanofi Aventis R\&D, 1 avenue Pierre Brossolette, 91380 Chilly-Mazarin, France.

${ }^{\perp}$ Sanofi, 153 2nd Ave, Waltham, MA 02451, USA

KEYWORDS. PCSK9, Pep2-8, SIP technology, Stapled peptides, LDL uptake. 


\section{ABSTRACT}

Proprotein convertase subtilisin/kexin type 9 (PCSK9), identified as a regulator of low-density lipoprotein receptor (LDLR), plays a major role in cardiovascular diseases (CVD). Recently, Pep28, a small peptide with discrete three-dimensional structure was found to inhibit the PCSK9/LDLR interaction. In this paper, we describe the modification of this peptide by using stapled peptide and SIP technologies. Their combination yielded potent compounds such as $\mathbf{1 8}$ that potently inhibited the binding of PCSK9 to LDLR $\left(\mathrm{K}_{\mathrm{D}}=6 \pm 1 \mathrm{nM}\right)$ and restored in vitro LDL-uptake by HepG2 cells in the presence of PCSK9 $\left(\mathrm{EC}_{50}=175 \pm 40 \mathrm{nM}\right)$. The three-dimensional structures of key peptides were extensively studied by circular dichroism and nuclear magnetic resonance, and molecular dynamics simulations allowed us to compare their binding mode to tentatively rationalize structure-activity relationships (SAR).

\section{INTRODUCTION}

Numerous genetic and clinical studies established that high levels of circulating low-density lipoprotein cholesterol (LDLc) are a major risk factor for developing atherosclerotic cardiovascular diseases (ASCVD), a leading cause of all deaths worldwide. ${ }^{1-3}$ Therefore, academic and industry scientists have paid considerable attention to developing therapeutics that decrease the level of LDLc for treating hypercholesterolemia. For more than thirty years statins have been the first-line treatment to reduce both LDLc levels and cardiovascular events. While they are highly effective, they have several limitations due to their reported side effects such as myopathy, gastrointestinal symptoms and elevated liver enzymes. ${ }^{4-7}$ In the 2000 s, proprotein convertase 
subtilisin/kexin type 9 (PCSK9) has emerged as a novel target for lowering LDLc levels. The correlation between PCSK9 and the level of LDLc in human serum was first established by Abifadel et al. who discovered that PCSK9 missense mutations cause autosomal dominant form of familial hypercholesterolemia. ${ }^{8}$ Conversely, it has been shown that gain-of-function mutations in the $p c s k 9$ gene are associated with higher levels of LDLc and a higher risk of cardiovascular disease. ${ }^{9-12}$ PCSK9 regulates the level of plasma LDLc through its binding to LDL receptor (LDLR) on the cell surface. The PCSK9/LDLR complex is internalized through endocytosis and directed to the lysosomes for degradation, preventing LDLR recycling. ${ }^{13}$

Owing to the pivotal role of PCSK9 in cholesterol homeostasis, different approaches have been pursued to develop PCSK9 inhibitors. ${ }^{14-16}$ The most successful ones rely on the inhibition of PCSK9/LDLR interaction. Two approved monoclonal antibodies (mAbs), evolocumab (Amgen) and alirocumab (Sanofi \& Regeneron), are currently used for the treatment of familial hypercholesterolemia and in patients who do not properly respond to statins. ${ }^{17,18}$ Alternative strategies to mAbs aiming at reducing PCSK9 plasma levels or inhibiting PCSK9/LDLR interactions are currently at various stages of development, including small interfering RNA (siRNA) such as inclisiran, ${ }^{19}$ antisense oligonucleotides, adnectins, vaccines, small molecules or peptides. ${ }^{20}$ This last family of inhibitors represent a promising alternative in the middle space between large biological agents, like mAbs, and small molecules for disrupting the protein-protein interactions (PPI) between PCSK9 and the large $\left(530 \AA^{2}\right)$ and relatively flat EGF-A domain of LDLR,${ }^{21}$ as highlighted by the crystal structure of the PCSK9/EGF-A complex (PDB: 3BPS). ${ }^{22,23}$ Several peptides or peptidomimetics have been shown to induce LDLR degradation in vitro and in vivo and were able to restore the LDL uptake in cells. They were identified by using different approaches, that include structure-based rational approaches from the peptide sequence of EGF-A 
domain, ${ }^{24,25}$ natural peptides derived from lupin protein hydrolysis preventing the interaction between PCSK9 and LDLR, ${ }^{26}$ or phage display ${ }^{27,28}$ mRNA display ${ }^{29}$ and recently CRISPR base editors technologies. ${ }^{30}$ Using mRNA display technology followed by an optimization process, Alleyne et $a .^{29}$ found bicyclic peptides that potently inhibit PCSK9/LDLR interaction and constitute potential candidates to move towards the development of orally bioavailable PCSK9 inhibitors. The screening of phage-displayed peptide libraries has enabled the group of Kirchhofer to first identify 20 -mer peptides ${ }^{27}$ and then Pep2-8, a 13 amino acid long peptide, as PCSK9 competitive inhibitors. ${ }^{28}$ Although Pep2-8 arouses great interest, it suffers from a fairly low binding affinity $(0.7 \mu \mathrm{M})$ and neutralizes PCSK9 activity, with an $\mathrm{IC}_{50}$ of $12.5 \mu \mathrm{M}$ for LDLR restoration and $12.5 \mu \mathrm{M}$ for LDL-uptake in HepG2 cells. It was subsequently modified to generate new peptides with improved activity. ${ }^{31-34}$ Besides these different approaches, advanced computational strategies allowed the discovery of small peptidomimetics that disrupt the PCSK9/LDLR PPI and inhibit PCSK9 activity. ${ }^{35,36}$

All these studies point out the interest for peptides as an alternative strategy to small molecules or biologics for providing candidates able to potently inhibit the PCSK9-LDLR interaction. Although proteolytic and/or conformational instability often impairs the development of peptides as therapeutic candidates, this liability may be overcome by using stabilizing systems. In this report, we focus on introducing several modifications to Pep2-8 aimed at enhancing its activity. First of all, using stapled peptide technology, widely used in medicinal chemistry for helix stabilization, ${ }^{37-39}$ we introduced two different types of stapling braces on specific positions of the helical part of Pep2-8, notably all-hydrocarbon and Lys/Asp lactam staples (Figure 1B). ${ }^{40,41}$

Secondly, we applied the structure-inducing probes (SIP) technology to Pep2-8 and derivatives (Figure 1B). This technology consists in adding a charged amino acid patch (e.g. lysine or glutamic 
acid) at the C-terminus of a targeted peptide sequence. ${ }^{42-44}$ The charged amino acid patch can induce a helical conformation in peptide sequences and act like a shield against enzymatic degradation. It can reduce peptide aggregation during the synthesis of peptides that undergo aggregation and improves peptide solubility. Although the presence of the positively charged Lys patch may be suspected to induce some side effects, it was successfully used in active peptide sequences including the recently disclosed RXFP1 agonist peptides and for the development of the potent GLP-1 receptor agonist, Lixisenatide. ${ }^{45-48}$ In this study, we hypothesized that besides the reported properties of the Lys patch, its introduction at the C-terminus of Pep2-8 derivatives would lead to additional electrostatic interactions with proximal negative side chains at the PCSK9 surface (Figure 1C). 


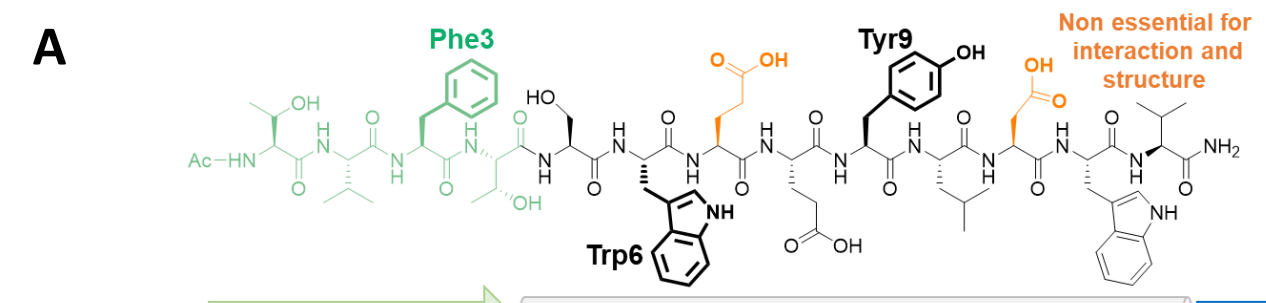

Strand

Helix

Lys extension

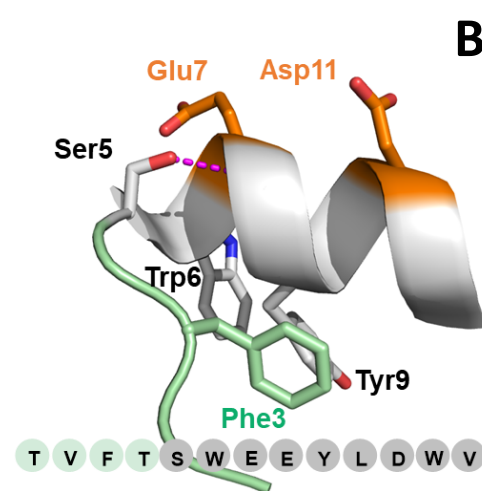

B Lys patch

T V F T S W E E Y L D W V K K K

T V F T S WEE Y L DWVKKKKKK

1

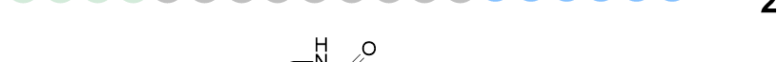

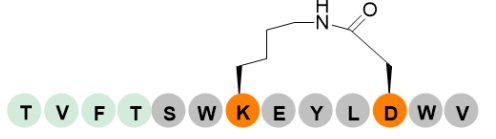

3

Stapled

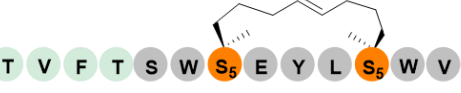

T VFTSWKEYLDWVKKK

Pep2-8

C

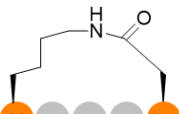

6

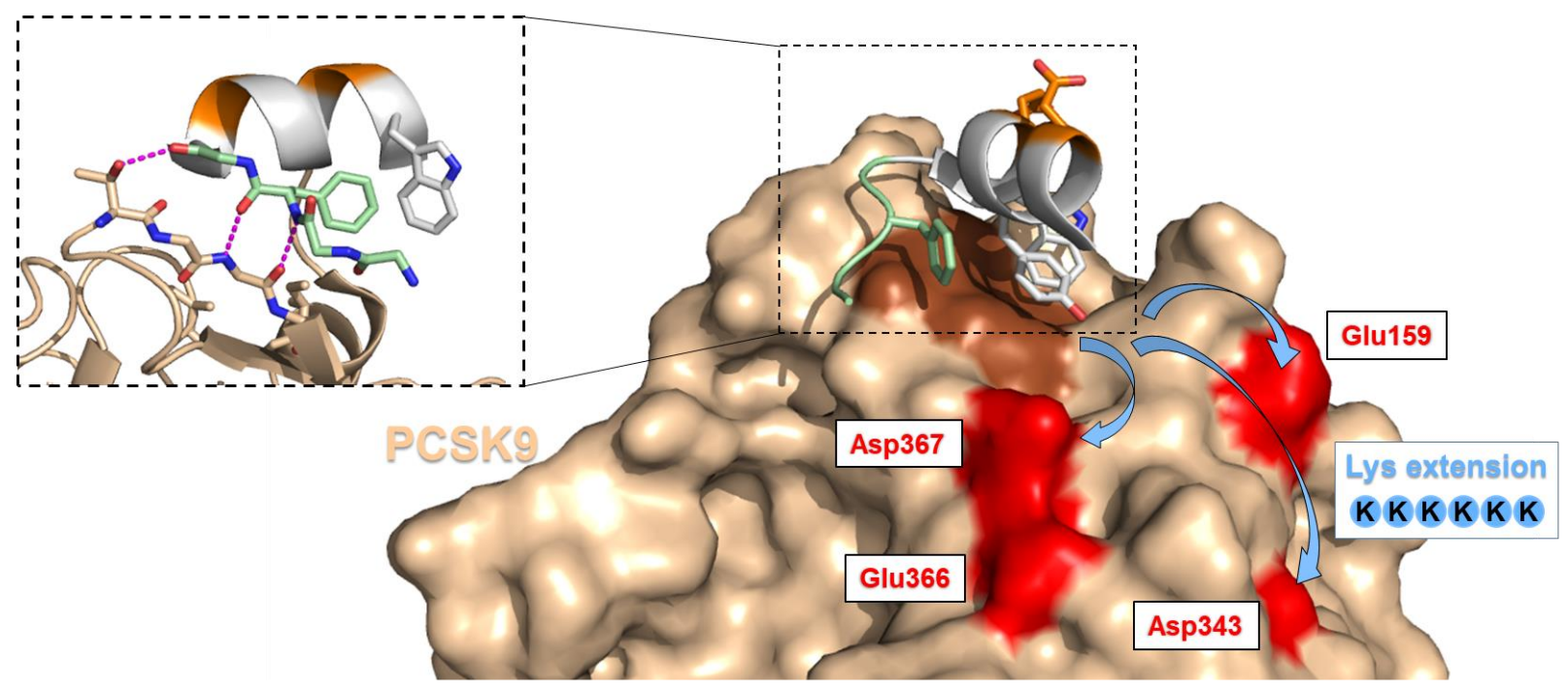

Figure 1. (A) Sequence of Pep2-8, The three crucial residues for structure stabilization and binding to PCSK9 are in bold; (B) Sequences of the first series of Pep2-8 derivatives; (C) Pep2-8/PCSK9 crystal structure (PDB: 4NMX). Pep2-8/PCSK9 intermolecular hydrogen bonds are shown as pink dashed lines. 
Finally, we synthesized stabilized EGF-A/Pep2-8 chimeric peptides and mutants to increase the affinity of Pep2-8 for PCSK9. All peptides were tested for their ability to bind PCSK9 by surface plasmon resonance (SPR) and the most representative peptides were selected for LDL-uptake assay in HepG2 cells. We obtained stapled analogs with 1000 -fold better affinity than Pep2-8 that efficiently restored the LDL-uptake in vitro. We characterized the three-dimensional structures of the derivatives via extensive CD and NMR studies. Molecular Dynamic (MD) simulations of the Pep2-8/PCSK9 complexes were then performed to tentatively rationalize the relationship between the three-dimensional structures and the binding mode of the Pep2-8 derivatives and their affinities for PCSK9.

\section{RESULTS AND DISCUSSION}

\section{Design and Synthesis of Pep-2-8 analogs.}

The reference Pep2-8 peptide and its analogs were synthesized on AmphiSpheres RAM resin according to standard manual Fmoc/tBu solid phase peptide synthesis (SPPS). In the first series of analogs, the main modifications were performed according to the SIP and stapled peptide technologies. A C-terminal Lys patch of 3 and 6 lysine residues (peptides $\mathbf{1}$ and $\mathbf{2}$, respectively) and lactam or hydrocarbon staples were introduced at positions 7 and 11 of Pep2-8 after substitution of Glu7 and Asp11 by appropriate amino acids (peptides 3 and 4, respectively) (Figure 1). The choice of this specific positions for the introduction of the staple is based on the results of the alanine scanning performed by Zhang et al. ${ }^{28}$ that we confirmed in this study (Table S1). Indeed, the Glu7 and Asp11 residues are present on the hydrophilic face of the helix exposed to solvent and are not essential for either interaction with PCSK9 or the folding and stability of the Pep2-8 three-dimensional structure. The intramolecular cyclization were directly performed on 
resin, between a Lys and Asp residues for lactamization, ${ }^{49}$ and by ring-closing metathesis between two (S)-2-(4'pentenyl)-alanine (S5) residues using Grubbs catalyst. ${ }^{50}$ Peptides 5 and $\mathbf{6}$ combining both modifications, and the second series of peptides (7-18) resulting from a SAR study, were synthesized according to the same strategy.

\section{Structure of Pep2-8: CD signature and NMR diagnostic NOE correlations.}

Pep2-8 adopts a strand-turn-helix conformation, both in solution and in a complex with PCSK9 (PDB: 4NMX) (Figure 1). Its compact fold is stabilized by a strong hydrophobic core mainly involving Phe3, Trp6 and Tyr9, and a key hydrogen bond between the Ser5 side chain and the amide proton of Glu8 (Figure 1B). This hydrophobic patch is a main contributor to PCSK9 binding by forming van der Waals contacts (Figure 1C). Trp12 and Val13 also contribute to the hydrophobic patch but to a lesser extent, and are not in contact with PCSK9, while the Val2 side chain establishes important interactions with the target. Finally, reciprocal backbone hydrogen bonds involve Phe3 in the Pep2-8 sheet moiety and Phe379 in PCSK9, and a hydrogen bond involves the Thr4 carbonyl and Thr377 side chain hydroxyl group (Figure 1C).

First, we recorded the CD signature of Pep2-8 and gathered NMR diagnostic NOE correlations of the Pep2-8 hydrophobic patch and C-terminal helix, then determined the Pep2-8 solution structure (Figure 2, Figure S2). The combination of these structural probes allowed us to quickly monitor both the structural integrity and stability of the Pep2-8 analogs.

The Pep2-8 CD signature exhibited a strong negative maximum around $206 \mathrm{~nm}$ with a slight shoulder near $218 \mathrm{~nm}$ dominated by the contribution of the C-terminal helix, while the highly organized aromatic chromophores involved in the Pep2-8 hydrophobic patch gave rise to a small $\mathrm{CD}$ band centered around $230 \mathrm{~nm}$ (Figure 2A). Thus, the negative shoulder at $220 \mathrm{~nm}$ resulted from both the contributions of the helix and hydrophobic patch elements. We detected typical HN- 
$\mathrm{H} \alpha(i, i-3), \mathrm{HN}-\mathrm{H} \alpha(i, i-4), \mathrm{H} \alpha-\mathrm{H} \beta(i, i+3)$ NOEs in the 6-13 helix region, and unambiguous NOEs in the hydrophobic patch maintaining the Pep2-8 tertiary structure between the aromatic ring protons of Phe3/Tyr9 and Trp12, and Phe3/Trp6 and Tyr9 (Figure 2C-D). As expected, the Pep2-8 NMR structures adopted a strand-loop-helix fold and could be well-superimposed with the crystal and the NMR structures previously reported (Figure 2E, Figure S2). ${ }^{28}$
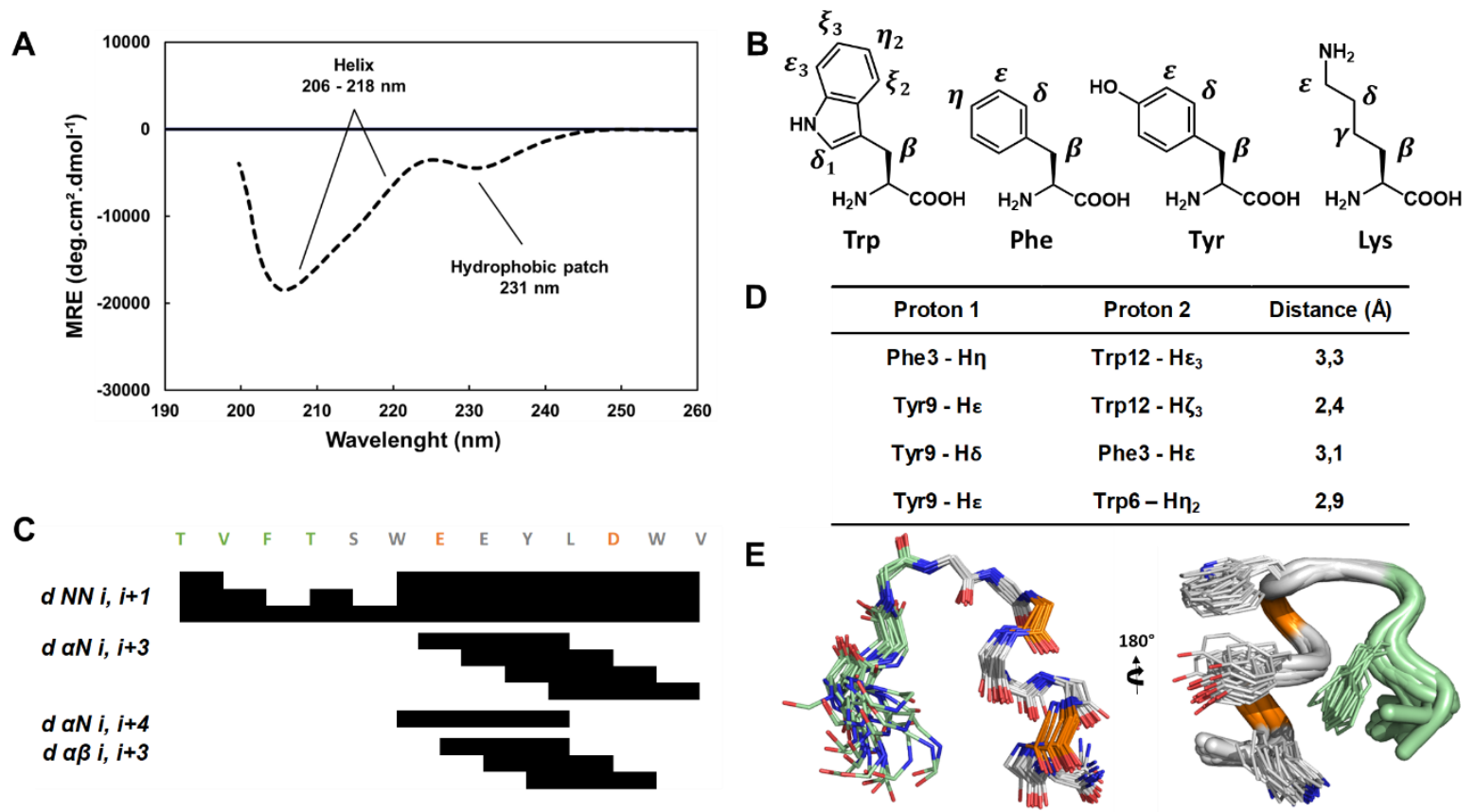

Figure 2. Pep2-8 structural probes. (A) CD signature of Pep2-8 in PBS at $20^{\circ} \mathrm{C}, \mathrm{pH}$ 6.5. (B) Side chains nomenclature of Trp, Phe, Tyr and Lys. (C) Typical backbone NOE correlations of Pep28. (D) Short key proton-proton distances measured in the PCSK9/Pep2-8 complex structure (PDB: 4NMX) given rise to unambiguous NOE correlations in the aromatic patch. (E) Superimposition of the Pep2-8 NMR 20 lowest-energy structures.

\section{Affinities of Pep2-8 stapled peptides and C-terminal lysine patches for PCSK9}

We wondered if the addition of lysine residues (peptides $\mathbf{1}$ and 2, respectively) could form additional interactions with the acidic surface of PCSK9 observed in the Pep2-8/PCSK9 complex 
crystal structure (Figure 1C, PDB: 4NMX) ${ }^{28}$ In particular, we hypothesized that the side chains of the C-terminal lysine patch could interact with the carboxylate groups of Glu159, Asp343 and Glu366/Asp367 located in a radius of less than $20 \AA$ of the Pep2-8 C-terminal extremity, and would enhance the analogs affinity for PCSK9 (Figure 1C).

The binding affinity $\left(\mathrm{K}_{\mathrm{D}}\right)$ of all peptides for PCSK9, including that of the reference peptide Pep2-8, was evaluated by surface plasmon resonance (SPR) (Table 1, Figure S3-S4). In our hands, Pep2-8 had a $K_{D}$ value of $9.7 \pm 0.2 \mu \mathrm{M}$ for PCSK9, which is close to the values previously reported. ${ }^{28}$

The addition of three C-terminal Lys residues to Pep2-8 sequence enhanced its affinity for PCSK9 by about 6-fold (peptide $1, \mathrm{~K}_{\mathrm{D}}=1.6 \mu \mathrm{M}$ ). Interestingly, when six Lys residues were added, we observed a significant increase in affinity for PCSK9. Indeed, peptide $\mathbf{2}$ exhibited a $K_{D}$ value of $0.424 \mu \mathrm{M}$ corresponding to a $\sim 20$-fold increase in binding affinity compared to Pep2-8 (Table 1).

Table 1. Binding affinity of Pep2-8 analogs

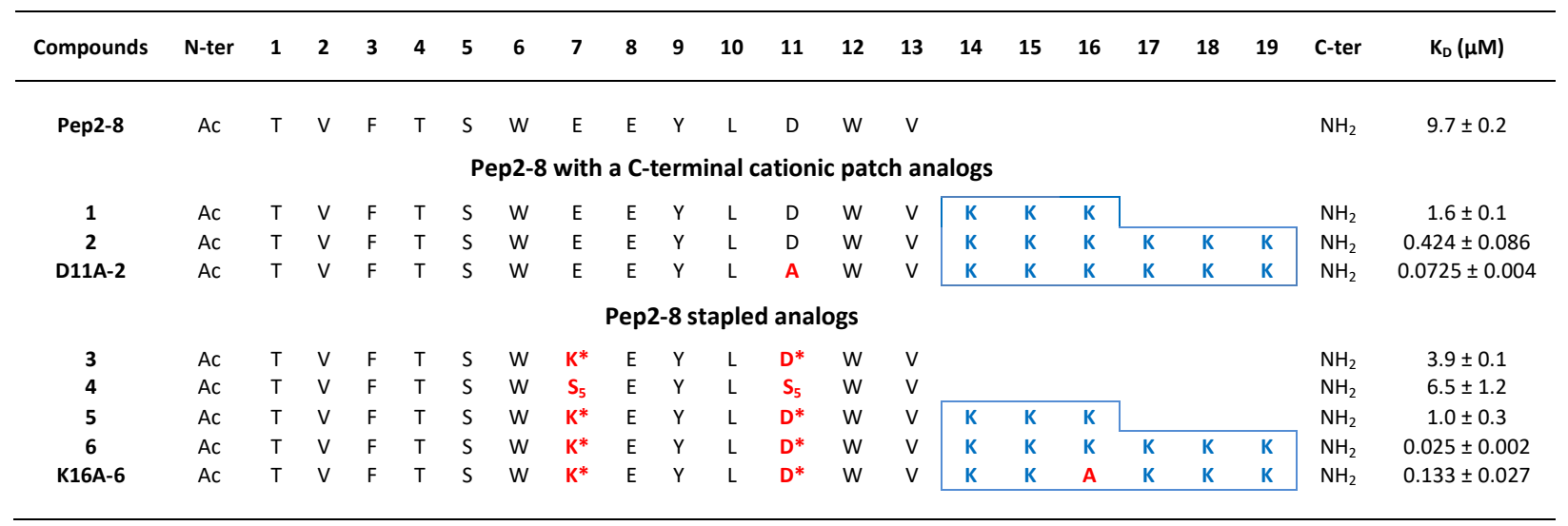

In order to stabilize the helix, we incorporated lactam and hydrocarbon bridges between positions 7 and 11 in the helix of Pep2-8, as well as in the lysine Pep2-8 analogs. As mentioned 
above, the side chains of the residues Glu7 and Asp11 are projected on the opposite face of the Pep2-8/PCSK9 interface and have been shown not to be important for the binding to PCSK9. Peptide S7 (Ala7-[Pep2-8]), and peptide S11 (Ala11-[Pep2-8]) exhibited $\mathrm{K}_{\mathrm{D}}$ values of $7.0 \mu \mathrm{M}$ and $8.6 \mu \mathrm{M}$, respectively, Table S1). Peptides 3 and $\mathbf{4}$ were able to bind PCSK9 with almost the same affinity as Pep2-8 ( $\mathrm{K}_{\mathrm{D}}$ of 3.9 and $6.5 \mu \mathrm{M}$, respectively). The results showed that the introduction of either a hydrocarbon or a lactam staple onto Pep2-8 did not impact its binding affinity since it already adopted a stable strand-turn-helix structure.

By combining stapled peptide and SIP technologies, we incorporated the lactam bridge onto peptides $\mathbf{1}$ and $\mathbf{2}$ leading to peptides $\mathbf{5}$ and $\mathbf{6}$, respectively. Considering the comparable affinities measured with lactam and hydrocarbon staples, we focused on the lactam bridge because of the low solubility of the peptides containing the hydrocarbon staple, devoid of lysine patches.

The addition of three lysine residues at the $\mathrm{C}$-terminus of peptide 3 led to peptide 5 ( $\mathrm{K}_{\mathrm{D}}=1.0$ $\mu \mathrm{M})$ that had a similar affinity as the analogous linear peptide $1\left(\mathrm{~K}_{\mathrm{D}}=1.6 \mu \mathrm{M}\right)$, while the introduction of six lysine residues at the C-terminus of the lactam-bridged peptide dramatically increased its binding affinity for PCSK9 (peptide $6, \mathrm{~K}_{\mathrm{D}}=0.025 \mu \mathrm{M}$ ). This peptide displayed about a 400-fold better binding affinity than Pep2-8. Therefore, we evaluated the impact of the number of C-terminal lysine residues on the structure and the binding mode of Pep2-8 and its lactamstapled peptide analog.

\section{D structure of Pep2-8 analogs and binding mode on PCSK9}

Pep2-8 analogs, except peptide 4, which was poorly soluble and could not be studied, shared comparable CD signatures to Pep2-8 with slight shifts of the negative bands (Figure 3A). In addition, for peptides 1-3 and 6, NMR studies showed that we retrieved the characteristic backbone 
and aromatic patch NOEs correlations of the strand-loop-helix structure of Pep2-8 (Figure 3B-C). Such results indicated that the addition of a lysine patch or the incorporation of a staple to Pep2-8 did not affect its overall folding. The main differences among the various CD signatures were variations of the signal intensities (Figure 3A). The global increase to various extent of the negative bands around 207 and $230 \mathrm{~nm}$ could be related to variations of the $\alpha$-helical content of the peptides depending on the presence of the Lys patch and/or the staple. Concomitantly to the negative contribution of the $\alpha$-helix at $208 \mathrm{~nm}$, the second at $220 \mathrm{~nm}$ also increased but was partially masked by the Cotton effects from the aromatic patch around $230 \mathrm{~nm}$. Peptides $\mathbf{1}$ and $\mathbf{2}$ showed a global increase of the negative bands around 207-208 nm and $230 \mathrm{~nm}$, suggesting that the lysine patch should at least partially extend the C-terminal helix. Nevertheless, the negative maxima of the spectrum of peptide 2 was slightly weaker than that of $\mathbf{1}\left(\theta_{222}=-12299 \mathrm{deg} \cdot \mathrm{cm}^{2} \cdot \mathrm{dmol}{ }^{-1}\right.$ and -11457 deg. $\mathrm{cm}^{2} \cdot \mathrm{dmol}^{-1}$, for peptides $\mathbf{1}$ and $\mathbf{2}$ respectively), while we expected its mean residual ellipticity at $222 \mathrm{~nm}$ to increase if the six-lysine patch was fully helical. This data indicated that the cationic patch composed of six Lys in peptide 2 may be partially disordered. We hypothesized that electrostatic repulsions of the C-terminal positively-charged Lys side chains may prevent the helical folding of the six-lysine patch, as observed for the homopolypeptide poly-L-lysine (PLL). ${ }^{51}$ Indeed, while we globally detected the characteristic helix NOE pattern, i.e. HN-H $\alpha(i, i-3), \mathrm{HN}-$ $\mathrm{H} \alpha(i, i-4), \mathrm{H} \alpha-\mathrm{H} \beta(i, i+3)$, over the entire $\alpha$-helix moiety in peptide 1 including the three extra-lysine residues, the medium-range NOEs involving the last three lysine residues could not be detected in peptide $\mathbf{2}$ (Figure 3C). As expected, the NMR structure of peptide $\mathbf{2}$ is comparable to the structure of Pep2-8 with a partially disordered C-terminal lysine tail (Figure 3D). The helix ranged from residues 5 to 15 in peptide 2 while the K16 to K19 fragment did not converge. The backbone RMSD from residues 2 to 13 was $1.1 \AA$ and dramatically rose up to $2.1 \AA$ when the C-terminal 
extension was included. Interestingly, additional features involving the Lys extension arose from the NMR structures of peptide 2 compared to Pep2-8. We observed in almost all structures salt bridges between Asp11 and/or Lys14/15 and a strong cation- $\pi$ interaction between Trp12 and Lys 16 side chains stabilizing the last helix turn. Although we failed to unambiguously detect NOEs peaks between the Asp11 and Lys14/15 side chains protons in both peptides 1 and 2 NOESY spectra, we detected NOEs correlations between the Trp12 and Lys16 side chains protons, i.e. $\operatorname{Trp} 12 . \mathrm{H} \delta_{1}, \mathrm{H} \zeta_{2}-\mathrm{Lys} 16 . \mathrm{H} \gamma ; \operatorname{Trp} 12 . \mathrm{H} \zeta_{2}-\mathrm{Lys} 16 . \mathrm{H}_{\delta}$. In addition, the side chains protons of Lys16 were significantly shielded compared to those of Lys14 and 15 (Table S3-S4). No medium-range NOEs could be detected involving the last three lysine 16-19 side chains (Figure 3C).

\section{A}

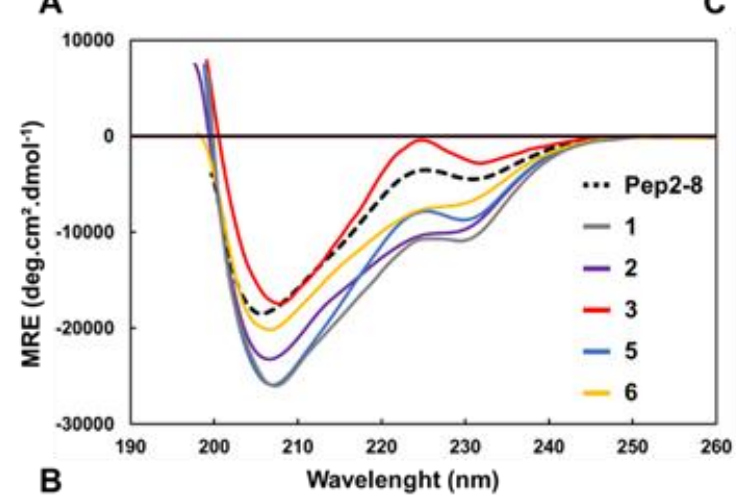

B

\begin{tabular}{|c|c|c|c|c|c|c|}
\hline Proton 1 & Proton 2 & Pep2-8 & 1 & 2 & 3 & 6 \\
\hline Phes. $\mathrm{Hn}$ & Trp12 $\cdot \mathrm{Hc}$, & ress & Yes & Yes & Ano & Yes \\
\hline Tyro. $\mathrm{He}_{\mathrm{k}}$ & Tip12 $\cdot \mathrm{HZ}$ & res & Yos & no & res & Yes \\
\hline Tyrs - Ho & mos. $\mathrm{He}$ & ros & Yes & res & Ne & Nes \\
\hline $\mathrm{Tyrs} \cdot \mathrm{Me}$ & $T_{\mathrm{pp} 6}=\mathrm{Hn}_{3}$ & Yes & res & res & No & Yes \\
\hline
\end{tabular}

D

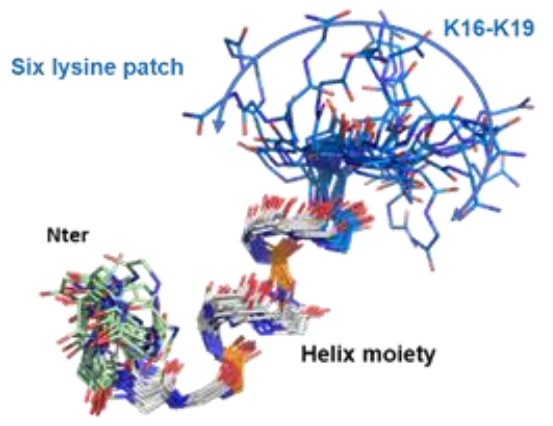

C

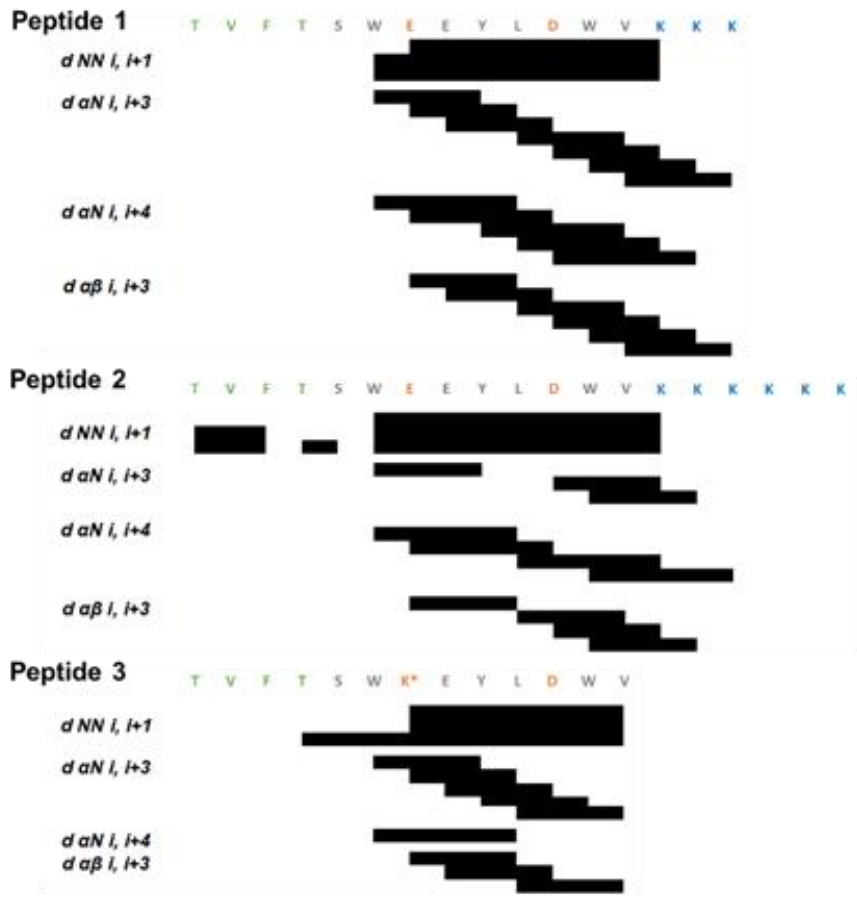

Peptide 6

$d N N 1,1+1$

$d a N i, 1+3$

$d a N i, i+4$

$d \alpha \beta 1,1+3$

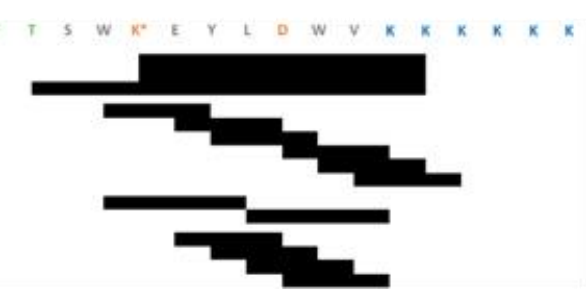


Figure 3. (A) CD spectra of Pep2-8, peptides 1-3 and 5, 6 in $\mathrm{PBS}$ at $20^{\circ} \mathrm{C}, \mathrm{pH}$ 6.5. Diagnostic NOE correlations of Pep2-8 and analogs. (B) Table of the characteristic NOEs of the aromatic patch (unambiguously detected NOEs are annotated as 'Yes', 'Amb' for ambiguous NOEs and 'No' when the correlation could not be detected. (C) Sequential and medium-range NOEs typical of peptide 1-3 and 6 secondary structures. (D) NMR solution structures of peptide 2 . The side chains were omitted for clarity. The $\mathrm{N}$-terminal strand is colored in green and the lysine patch in blue.

Similarly, the CD spectra of Pep2-8 and stapled peptides 3, 5 and $\mathbf{6}$ shared similar shapes with slight shifts of the negative band around 206-208 $\mathrm{nm}$ and major variations of the CD signal intensity for peptides 5 and $\mathbf{6}$ (Figure 3A). The lactam stapling of Pep2-8 leading to peptide $\mathbf{3}$ did not affect either the overall structure nor the stability of the strand-loop-helix fold. Likewise for peptides $\mathbf{1}$ and $\mathbf{5}$ with three C-terminal lysine shared similar signatures, however the CD profile of 5 showed a slight decrease of the negative maximum at $230 \mathrm{~nm}$. Peptide 6, containing both the staple and the six-lysine patch, showed a comparable tendency with lower negative maxima at 208 and $230 \mathrm{~nm}$ compared to 2 . Thus, the incorporation of lactam bridges did not further stabilize the Pep2-8 helix region and its Lys patch analogs $\mathbf{1}$ and $\mathbf{2}$ but to the contrary moderately decreased the helical content. NMR studies on peptide $\mathbf{6}$ confirmed what we had previously observed for peptide 2, i.e. the six-lysine patch remained partially unfolded despite the presence of the lactam bridge (Figure 3C-D). The modest decrease of the helical content for the stapled analogs $\mathbf{5}$ and $\mathbf{6}$ with three and six lysines could be explain by the engagement of the Asp11 side chain in the lactam bridge in position 7-11, preventing the formation of salt bridges in position 11-14/15. These latter may have a significant contribution to helix stabilization of these peptides. 

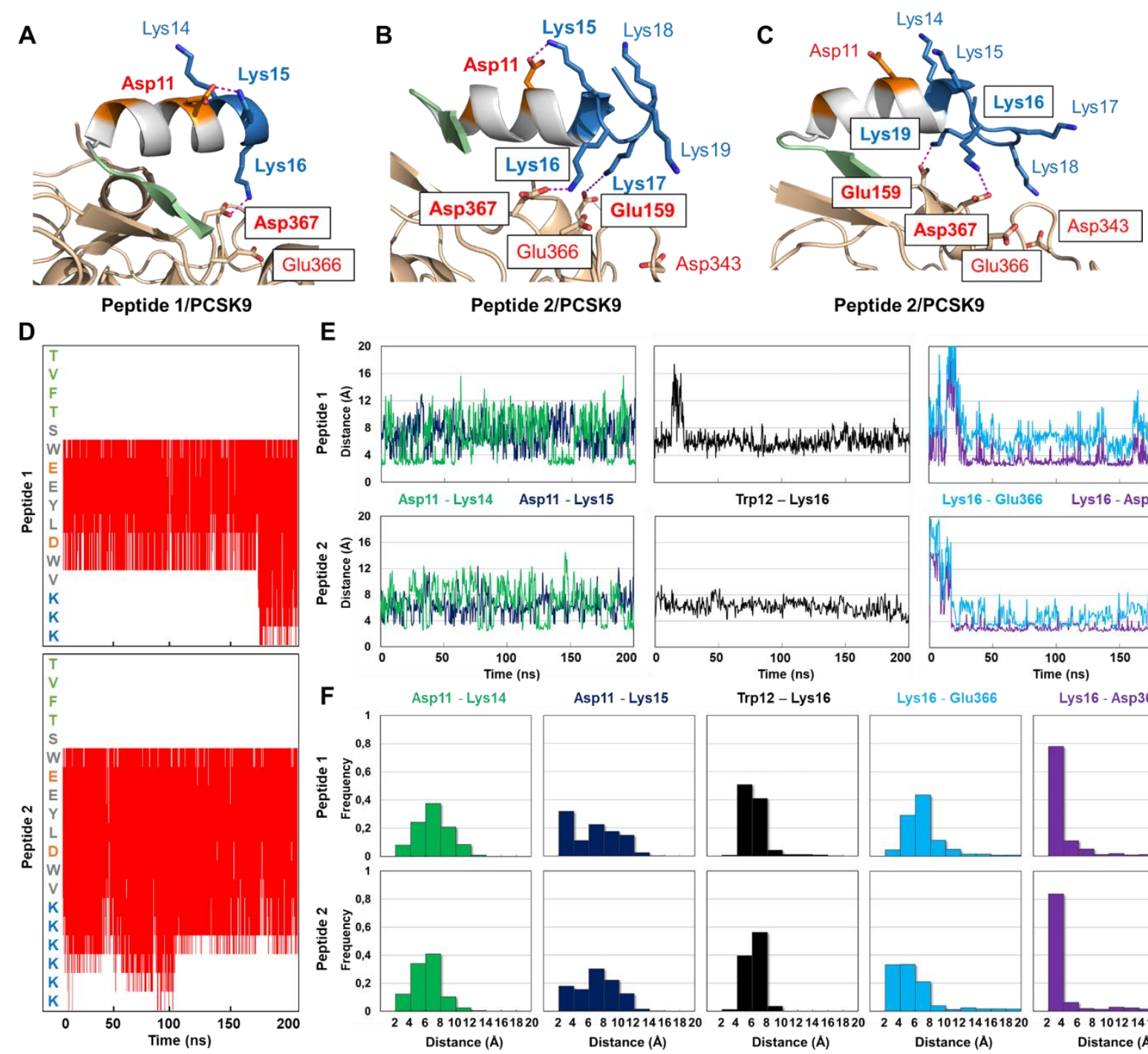

E

Peptide 2/PCSK9
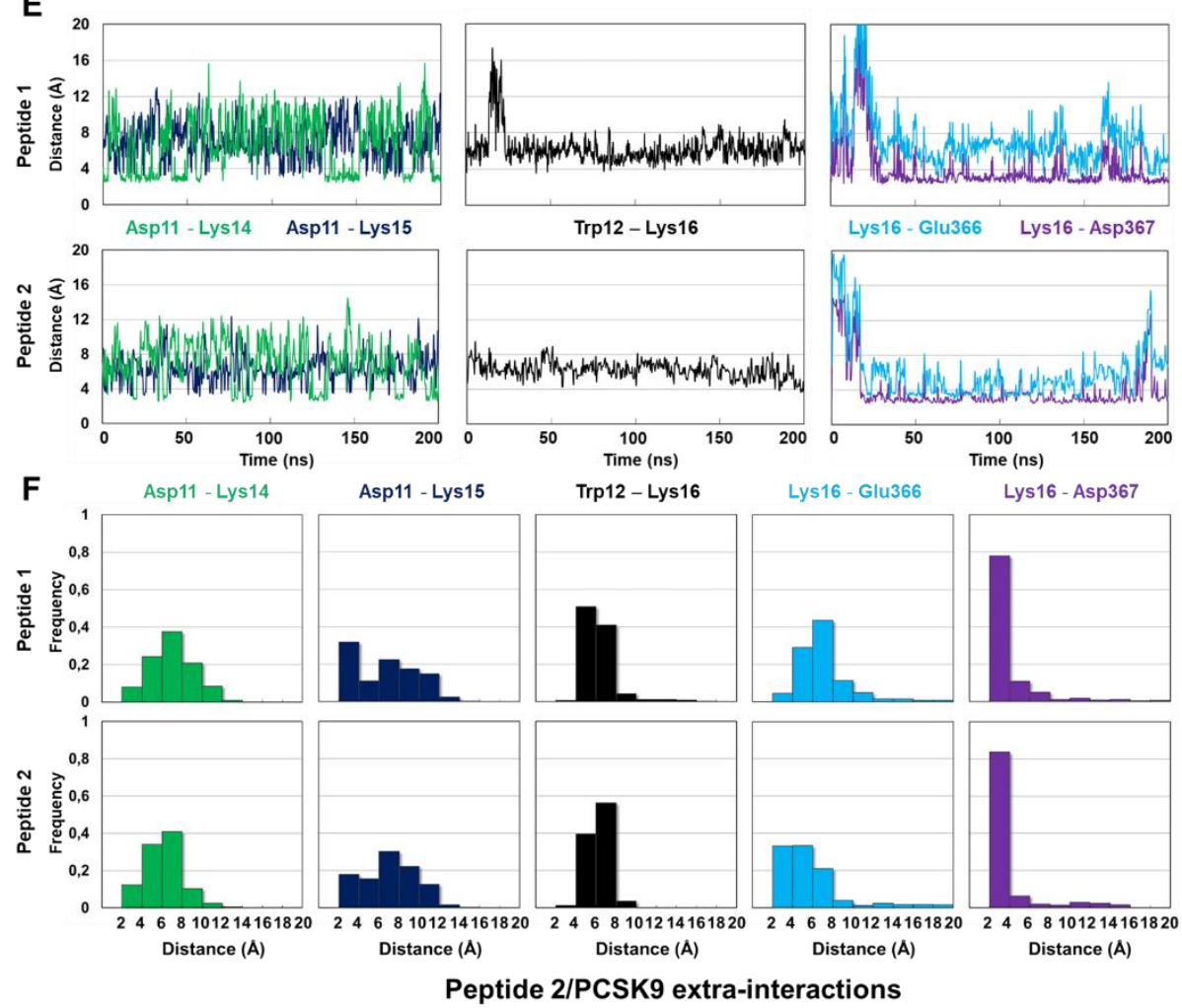

Figure 4. Representative MD snapshots of the binding interface of (A) peptide 1/PCSK9, and (BC) peptide 2/PCSK9. Residues involved in electrostatic interactions are highlighted (charged side chains are shown as sticks, main residues are labeled in bold). (D) Helix secondary structures heatmaps. The helix moieties in peptides $\mathbf{1}$ and $\mathbf{2}$ are shown in red. (E-F) Comparisons of key side chains distances $(\AA)$ and their distribution along the MD simulations of peptides $\mathbf{1}$ and $\mathbf{2}$ in complex with PCSK9. 
Since the global structure of Pep2-8 analogs was maintained within this first series of peptides, we further investigated their binding mode to explain the important PCSK9 affinity discrepancies. For that purpose, we performed MD simulations of peptides $\mathbf{1}$ and $\mathbf{2}$ in complex with PCSK9 starting from extended conformations of the lysine patches (Figure 4). Both peptides remained spontaneously in close contact with PCSK9 all along the simulations. The three C-terminal lysine residues in peptide 1 quickly adopted a nearly helical conformation with the formation of Asp11Lys 14/15 electrostatic and Trp12-Lys16 cation- $\pi$ interactions (Figure 4A shows the Asp11-Lys15 electrostatic interaction). Finally, peptide 1 showed a stable $\alpha$-helix structure from residues 6 to 16, from about $170 \mathrm{~ns}$ to the end of the simulation (Figures 4A, D-F). The distances between any of the oxygen atoms of Asp11 and the nitrogen atoms of Lys14 or Lys15 regularly fell under 3.2 $\AA$ along the simulation (represented in green and blue, respectively), while the distance between the Lys12 protonated amino group and the Trp16 indole ring ( $\mathrm{dN} \zeta-\mathrm{C} \varepsilon 2)$ oscillated around $6.3 \AA$ (Figure 4E, in black). For peptide 2, we observed similar intramolecular interactions (Figure 4EF) with an equilibrium between two conformations of the six-lysine patch driven by the formation and the opening of the Asp11 and Lys14/15 salt bridge. The presence of this interaction stabilizes the entire C-terminal lysine patch as a helix (Figure 4B) despite the electrostatic repulsive forces between the lysine amino groups on the same helix faces (e.g. Lys15-18, Lys16-Lys19) that lead to the conformation displayed in Figure 4C. Thus, the disruption of the Asp11-Lys14/15 salt bridge allows the last four lysine residues (Lys16-Lys19) to partially unfold to promote close contacts with the PCSK9 surface. Interestingly, we observed for both peptides $\mathbf{1}$ and $\mathbf{2}$ the establishment of a stable ionic bond between the Lys16 amino group and the carboxylate group of the Glu366/Asp367 residues of PCSK9 (Figures 4E-F). The salt bridge between Lys16 and Asp367 is particularly stable with a dN $\zeta-\mathrm{O} \delta$ distance mostly under $3.2 \AA$ from $40 \mathrm{~ns}$ for both $\mathbf{1}$ and $\mathbf{2}$ (in 
purple). This ionic bonding may explain the first gain in affinity when the lysine patches were present in both peptides 1 and $\mathbf{2}$ (Figures 4A-C, E-F). The gain in affinity for peptide $\mathbf{2}$ versus peptide $1\left(\mathrm{IC}_{50}=0.424 \pm 0.086\right.$ and $1.6 \pm 0.1 \mu \mathrm{M}$, respectively, Table 1$)$, albeit modest, could be explained by the overall impact of supplementary electrostatic interactions between Lys17/19 and the negative patch at the PCSK9 surface, while in both conformations Lys18 side chain was projected into the solvent and did not interfere with PCSK9 (Figures 4B-C, S16). These interactions were rather labile but became predominant in the last part of the simulation with the stabilization of the second binding mode in Figure 4C. Thus, one explanation of the 17-fold gain in affinity between peptides $\mathbf{2}$ and $\mathbf{6}$, could be that in the latter, Asp11 is engaged in the lactam bridge, leading exclusively to the binding mode as displayed in Figure $4 \mathrm{C}$ with optimized contacts for PCSK9. The Lys17 and Lys19 side chains quickly swing between the Glu159, Glu366 and Asp367 carboxylates (Figure S16). To summarize, the absence of Asp11-Lys14/Lys15 salt bridges may release the six lysine residues tail that could ideally adapt to the negative patches at the PCSK9 surface. We prevented the formation of these salts bridges by mutating Asp11 to an Ala in the sixlysine patch-derived peptide 2 (compound D11A-2). The binding affinity improvement of up to 5.8-fold ( $\mathrm{K}_{\mathrm{D}}$ of $0.0725 \mu \mathrm{M}$ instead of $0.424 \mu \mathrm{M}$ ) achieved for compound D11A-2, compared to peptide 2 supported this hypothesis. However, the single D11A mutation did not allow to totally recover the high affinity of compound $6\left(K_{D}=0.025 \mu \mathrm{M}\right)$, highlighting the benefit of having the staple into the peptide sequence. Furthermore, to validate the role of Lys16 in the interaction with E366 and D367 residues of PCSK9, we synthesized the K16A mutant (compound K16A-6). The decreased in affinity of compound K16A-6 compared to the reference compound 6 ( $\mathrm{K}_{\mathrm{D}}$ of 0.133 $\mu \mathrm{M}$ instead of $0.025 \mu \mathrm{M})$ is consistent with this assumption. 


\section{N-terminal strand modulation}

We focused on mutations within the N-terminal strand to improve the analogs affinity for PCSK9 (Table 2). The Pep2-8/PCSK9 structure shows tight contacts between the N-terminal strand residues of Pep2-8 and PCSK9. ${ }^{28}$ Deletion of Val2, as well as mutation of Val2 and Phe3 into Ala were detrimental for the Pep2-8/PCSK9 interaction (peptides S14, S2 and S3 respectively). It is noteworthy that the N-terminal strand of Pep2-8 fits well with the strand 306309 of the LDLR EGF-A domain interacting with PCSK9, as previously shown (Figure S1). ${ }^{28}$ Thus, we first synthesized the EGF-A/Pep2-8 chimeric sequence 7 corresponding to the T1H, F3C and T4N triple mutation in the Pep2-8 sequence. Unfortunately, peptide 7 did not bind to PCSK9 (Table 2). We found that this loss of affinity for PCSK9 was probably due to the loss of the Pep28 strand-loop-helix structure. Indeed, the CD signature of peptide 7 was comparable to those of the unfolded Ala-scan mutants (Figure S11). The strong negative maximum was shifted at $204 \mathrm{~nm}$, and the shoulder near $220 \mathrm{~nm}$ and the negative band at $231 \mathrm{~nm}$ disappeared. Moreover, most of the hydrophobic patch and N-terminal helix NOE probes could not be detected on the NOESY spectrum of 7 (Table S10). We hypothesized that this complete loss of structure of the chimeric analog 7 was specifically due to the F3C mutation since the F3A mutant (S3) was unfolded and did not bind to PCSK9. This finding emphasizes again the important role of the aromatic side chain at position 3 that is essential to the hydrophobic packing maintaining the compact Pep2-8 fold required for the presentation of the Pep2-8 key side chains to interact with PCSK9. 
Table 2. Binding affinity of N-terminal strand mutated analogs of Pep2-8.

\begin{tabular}{|c|c|c|c|c|c|c|c|c|c|c|c|c|c|c|c|c|c|c|c|c|c|c|}
\hline Cpd & $\mathrm{N}$-ter & 1 & 2 & 3 & 4 & 5 & 6 & 7 & 8 & 9 & 10 & 11 & 12 & 13 & 14 & 15 & 16 & 17 & 18 & 19 & C-ter & $K_{D}(\mu M)$ \\
\hline \multicolumn{23}{|c|}{ EGFA-Pep2-8 chimeric analogs and mutants } \\
\hline 7 & $A c$ & $\mathrm{H}$ & v & C & $\mathrm{N}$ & $\mathrm{s}$ & w & $\mathrm{E}$ & $E$ & $\mathrm{Y}$ & $\mathrm{L}$ & $\mathrm{D}$ & w & $\mathrm{v}$ & & & & & & & $\mathrm{NH}_{2}$ & NB \\
\hline 8 & $A c$ & H & v & $\mathrm{F}$ & $\mathrm{N}$ & $\mathrm{s}$ & w & $\mathrm{E}$ & $\mathrm{E}$ & $\mathrm{Y}$ & $\mathrm{L}$ & D & w & $\mathrm{v}$ & & & & & & & $\mathrm{NH}_{2}$ & $3.9 \pm 0.4$ \\
\hline 9 & $\mathrm{Ac}$ & H & v & $\mathrm{F}$ & $\mathrm{N}$ & $\mathrm{s}$ & w & $\mathrm{E}$ & $\mathrm{E}$ & $\mathrm{Y}$ & $\mathrm{L}$ & $\mathrm{D}$ & w & $\mathrm{v}$ & $\mathrm{K}$ & $\mathrm{K}$ & $\mathrm{K}$ & & & & $\mathrm{NH}_{2}$ & $1.1 \pm 0.2$ \\
\hline 10 & $A c$ & H & v & $\mathrm{F}$ & $\mathrm{N}$ & $\mathrm{s}$ & w & $\mathrm{E}$ & $\mathrm{E}$ & $\mathrm{Y}$ & $\mathrm{L}$ & D & w & $\mathrm{v}$ & $\mathrm{K}$ & $\mathrm{K}$ & $\mathrm{K}$ & $\mathrm{K}$ & $\mathrm{K}$ & $\mathrm{K}$ & $\mathrm{NH}_{2}$ & $0.264 \pm 0.106$ \\
\hline 11 & $A C$ & H & v & $\mathrm{F}$ & $\mathrm{N}$ & $\mathrm{s}$ & w & $\mathrm{K}^{*}$ & $\mathrm{E}$ & $\mathrm{Y}$ & $\mathrm{L}$ & D* & w & $\mathrm{v}$ & & & & & & & $\mathrm{NH}_{2}$ & $5.3 \pm 0.85$ \\
\hline 12 & $A C$ & H & $\mathrm{v}$ & $\mathrm{F}$ & $\mathrm{N}$ & $\mathrm{s}$ & w & $\mathrm{K}^{*}$ & $\mathrm{E}$ & $\mathrm{Y}$ & $\mathrm{L}$ & D* & w & $\mathrm{v}$ & $\mathrm{K}$ & $\mathrm{K}$ & $\mathrm{K}$ & & & & $\mathrm{NH}_{2}$ & $0.757 \pm 0.171$ \\
\hline 13 & Ac & H & $v$ & $\mathrm{~F}$ & $\mathrm{~N}$ & $\mathrm{~s}$ & w & $\mathrm{K}^{*}$ & $\mathrm{E}$ & $\mathrm{Y}$ & $\mathrm{L}$ & $\mathrm{D}^{*}$ & w & $v$ & K & K & $\mathrm{K}$ & $\mathrm{K}$ & $\mathrm{K}$ & $\mathrm{K}$ & $\mathrm{NH}_{2}$ & $0.019 \pm 0.003$ \\
\hline \multicolumn{23}{|c|}{ Mutations at positions 4 on $\mathrm{T} 1 \mathrm{H}$ analogs } \\
\hline 14 & $A c$ & $H$ & $\mathrm{v}$ & $\mathrm{F}$ & $\mathrm{R}$ & $\mathrm{s}$ & w & $\mathrm{E}$ & $\mathrm{E}$ & $\mathrm{Y}$ & $\mathrm{L}$ & $\mathrm{D}$ & w & $\mathrm{v}$ & & & & & & & $\mathrm{NH}_{2}$ & $0.865 \pm 0.1$ \\
\hline 15 & $A C$ & $\mathrm{H}$ & $\mathrm{v}$ & $\mathrm{F}$ & Orn & $\mathrm{s}$ & w & $\mathrm{E}$ & $\mathrm{E}$ & $\mathrm{Y}$ & $\mathrm{L}$ & $\mathrm{D}$ & w & $\mathrm{v}$ & & & & & & & $\mathrm{NH}_{2}$ & $1.1 \pm 0.02$ \\
\hline 16 & Ac & H & $\mathrm{v}$ & $\mathrm{F}$ & K & $\mathrm{s}$ & W & E & $\mathrm{E}$ & Y & $\mathrm{L}$ & $\mathrm{D}$ & w & v & & & & & & & $\mathrm{NH}_{2}$ & $1.2 \pm 0.2$ \\
\hline \multicolumn{23}{|c|}{ Staples variations on $6 \mathrm{~K}$ cationic patched and mutated $\mathrm{T} 1 \mathrm{H}, \mathrm{T} 4 \mathrm{R} / \mathrm{K}$ analogs } \\
\hline 17 & Ac & H & $\mathrm{v}$ & $\mathrm{F}$ & $\mathrm{R}$ & $\mathrm{s}$ & w & S5 & $\mathrm{E}$ & Y & $\mathrm{L}$ & S5 & w & v & $\mathrm{K}$ & $\mathrm{K}$ & $\mathrm{K}$ & $\mathrm{K}$ & $\mathrm{K}$ & $\mathrm{K}$ & $\mathrm{NH}_{2}$ & $0.007 \pm 0.001$ \\
\hline 18 & $\mathrm{Ac}$ & H & v & $\mathrm{F}$ & K & $\mathrm{s}$ & W & $\mathrm{K}^{*}$ & $\mathrm{E}$ & $\mathrm{Y}$ & $\mathrm{L}$ & D* & w & $\mathrm{v}$ & $\mathrm{K}$ & $\mathrm{K}$ & $\mathrm{K}$ & K & K & $\mathrm{K}$ & $\mathrm{NH}_{2}$ & $0.006 \pm 0.001$ \\
\hline
\end{tabular}

NB: no binding

Furthermore, we observed on ${ }^{1} \mathrm{H}$ NMR spectra that peptide 7 formed disulfide-bridged dimers involving the Cys3 side chains in PBS (Figure S6). Consequently, we synthesized peptide 8 with the $\mathrm{T} 1 \mathrm{H} / \mathrm{T} 4 \mathrm{~N}$ double mutation, thus preserving Phe3. Its $\mathrm{K}_{\mathrm{D}}$ value of $3.9 \mu \mathrm{M}$ was comparable to that of Pep2-8. As expected, the T1H/T4N mutant 8 exhibited the typical Pep2-8 CD signature, which confirmed the negative impact of the $\mathrm{F} 3 \mathrm{C}$ mutation on the chimeric peptide 7 structure and consequently on its binding to PCSK9 (Figure S11, Table S2). By using the SIP and stapled peptide technologies on the double-mutant peptide 8 to generate analogs 9-13, we obtained similar trends to those of the Pep2-8 derivatives 1-6 (Table 1 and 2). As observed for the first series, the incorporation of the six-lysine C-terminal patch drastically increased the binding affinity for PCSK9. Indeed, peptide 10 exhibited a $K_{D}$ of $0.264 \mu \mathrm{M}$. The lactam-bridged analogs 11 and 12 showed comparable affinity for PCSK9 to their linear counterparts 8 and $\mathbf{9}$, respectively. The stapling of the C-terminal six-lysine patched peptide $\mathbf{1 0}$ to yield $\mathbf{1 3}$ led to a strong affinity improvement for these analogs. Peptide $\mathbf{1 3}$ had a 500-fold higher affinity for PCSK9 than Pep2-8. 
Excepting peptide 7, Pep2-8 analogs had comparable CD profiles and thus, shared similar structural features (Figure S12). According to the results of both series, one can conclude that the most potent compounds combined a staple and a six-lysine C-terminal patch.

\section{Mutants with single-digit nanomolar affinities}

Finally, we focused on position 4 of the N-terminal strand to tentatively further increase the affinity of Pep2-8 analogs for PCSK9 (Table 2). According to the results of Lammi et al. showing the advantage of introducing a basic residue at position 4, we replaced the Asn residue of peptide $\mathbf{8}$ by different basic amino acids (Arg, Lys and Orn), and we combined this substitution with SIP and stapled technologies.

First, we showed that N4R, N4Orn and N4K mutations slightly decreased by about 3-fold the $\mathrm{K}_{\mathrm{D}}$ values of peptides $14\left(\mathrm{~K}_{\mathrm{D}}=0.9 \mu \mathrm{M}\right), \mathbf{1 5}\left(\mathrm{K}_{\mathrm{D}}=1.1 \mu \mathrm{M}\right)$ and $\mathbf{1 6}\left(\mathrm{K}_{\mathrm{D}}=1.2 \mu \mathrm{M}\right)$ compared to $\mathbf{8}$ $\left(\mathrm{K}_{\mathrm{D}}=3.9 \mu \mathrm{M}\right)$. Analogs 14-16 displayed the typical Pep2-8 CD signature (Figure S13). Taking all these results together, we synthesized new Pep2-8 analogs (17 and 18) combining the T1H mutation, a basic residue in position 4 ( $\mathrm{R}$ or $\mathrm{K}$ ), the $\mathrm{C}$-terminal six-lysine patch and a staple between positions 7 and 11 (Table 2). The combination of these different modifications resulted in a drastic increase of the affinity for PCSK9. Peptides $\mathbf{1 7}$ and $\mathbf{1 8}$ exhibited an about 1000-fold better affinity than Pep2-8, with $K_{D}$ values of 7 and $6 \mathrm{nM}$, respectively. We solved the NMR solution structures of the lead peptide 18 (Figure 5A-B). We obtained well-defined structures from Val2 to Lys15 (backbone RMSD of $0.3 \AA$ and $1.0 \AA$ if the three last lysine residues were included). As expected, analog 18 showed a similar fold as Pep2-8 and peptide 2. Similarly, to the six-lysine analog 2 , very few NOEs correlations could be detected for the last three lysines, i.e. Lys 16-19, as they remained disordered despite the presence of the lactam bridge in the first half of the helix. 
We observed the Trp12-Lys16 cation- $\pi$ interaction typically formed in the lysine patched analogs. As expected, the lactam bridge is oriented at the opposite face of the hydrophobic patch and cannot interfere with the peptide 18 binding to the PCSK9 surface. The Asp11 side chain being involved in the lactam bridge cannot form a salt bridge with the Lys15 carboxyl group. Consequently, peptide 18 may exclusively bind PCSK9 through the binding mode in Figure 4C with optimized contacts as described above.
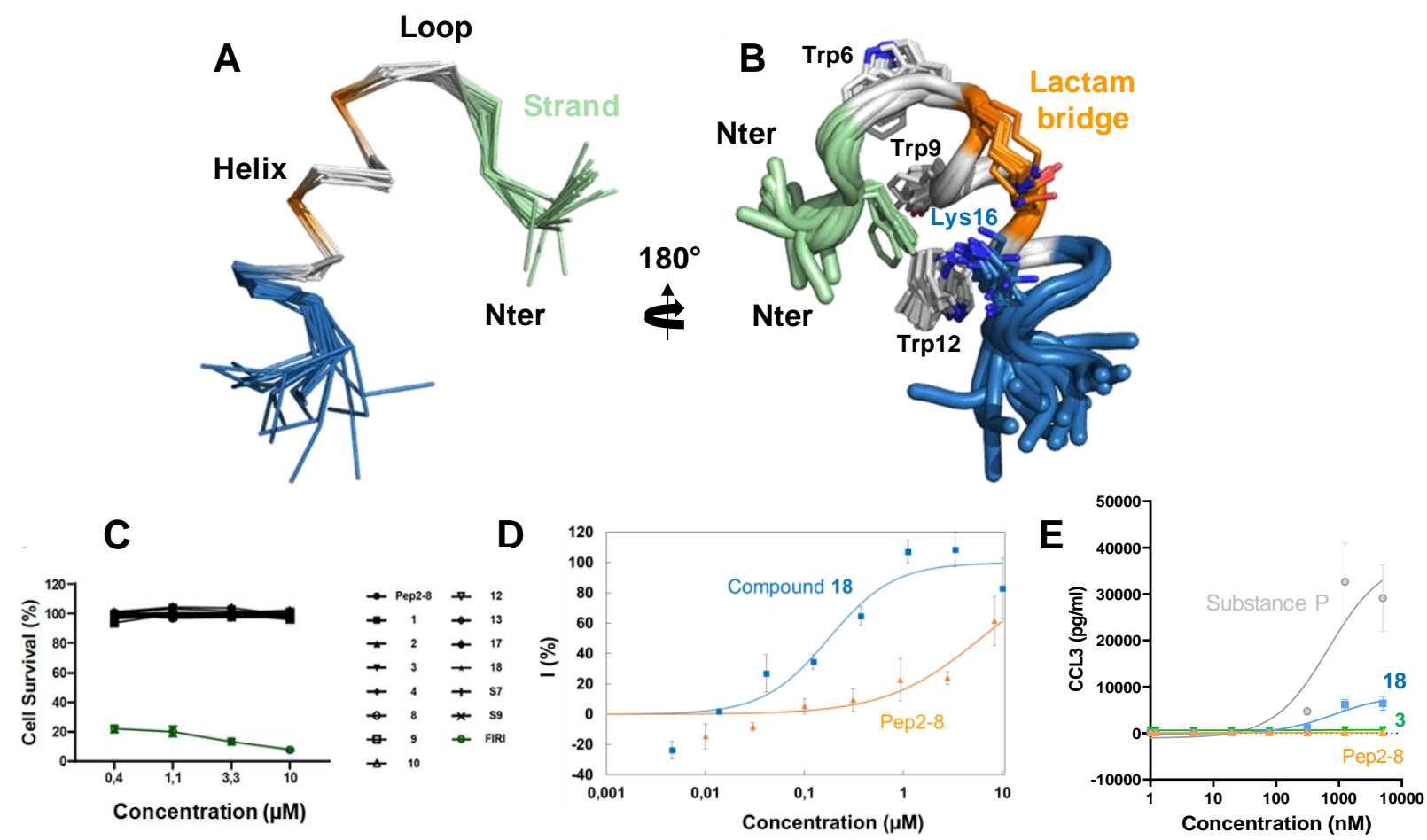

Figure 5. Superimposition of the 20 lowest-energy structures of peptide 18. (A) Ribbon backbone representation and (B) Cartoon representation, key side chains and the lactam bridge were represented as sticks. (C) Toxicity assays of representative Pep2-8 analogs against HepG2 cells. The cytotoxic Folfiri anticancer agent (FIRI) was reported as control. (D) LDL-uptake of Pep2-8 and lead peptide 18 in HepG2 cells, I(\%) : percent LDL BODIPY incorporation . (E) CCL3 release from LAD2 cells with peptides $\mathbf{3}$ and $\mathbf{1 8}$ compared to Pep2-8 and Substance P. 


\section{LDL uptake recovery in HepG2 cells, cell toxicity and mast cell degranulation}

We evaluated the toxicity and the ability of a set of representative Pep2-8 analogs to restore the LDL uptake on HepG2 cells, and we compared the results with that of the reference peptide Pep28 (Figure 5C-D, Table 3). First, all the tested peptides were not toxic against HepG2 cells. For the LDL uptake assays, we have selected peptide 1 containing the three-lysine patch, peptides 3 and $\mathbf{4}$ with two different types of stapling, peptide $\mathbf{8}$, and finally peptide $\mathbf{1 8}$ that combines all types of modifications. We measured the LDL uptake at a fixed concentration of $10 \mu \mathrm{M}$ for all peptides and for peptide 18, that exhibited the highest binding affinity, we determined its $\mathrm{EC}_{50}$.

Table 3. LDL uptake results with Pep2-8 and 1, 3, 4, 8 and 18.

\begin{tabular}{|c|c|c|c|c|c|c|c|c|c|c|c|c|c|c|c|c|c|c|c|c|c|c|}
\hline Cpd & $\mathbf{N}$-ter & 1 & 2 & 3 & 4 & 5 & 6 & 7 & 8 & 9 & 10 & 11 & 12 & 13 & 14 & 15 & 16 & 17 & 18 & 19 & C-ter & LDL uptake \\
\hline Pep2-8 & Ac & $\mathrm{T}$ & v & $\mathrm{F}$ & T & s & w & E & $\mathrm{E}$ & $\mathrm{Y}$ & L & $\mathrm{D}$ & w & V & & & & & & & $\mathrm{NH}_{2}$ & $\begin{array}{c}56.5 \pm 20.7^{\mathrm{a}} \\
6.0 \pm 1.6^{\mathrm{b}}\end{array}$ \\
\hline 1 & $\mathrm{Ac}$ & $\mathrm{T}$ & v & $\mathrm{F}$ & T & S & w & E & E & $\mathrm{Y}$ & L & D & w & v & $\mathrm{K}$ & $\mathrm{K}$ & $\mathrm{K}$ & & & & $\mathrm{NH}_{2}$ & $72.3 \pm 6.8$ \\
\hline 3 & Ac & $\mathrm{T}$ & v & $\mathrm{F}$ & T & $\mathrm{s}$ & w & $\mathrm{K}^{*}$ & E & $\mathrm{Y}$ & L & D* & w & v & & & & & & & $\mathrm{NH}_{2}$ & $52 \pm 6.3$ \\
\hline 4 & Ac & $\mathrm{T}$ & v & $\mathrm{F}$ & T & $\mathrm{s}$ & w & S5 & E & $\mathrm{Y}$ & $\mathrm{L}$ & S5 & w & v & & & & & & & $\mathrm{NH}_{2}$ & $42.7 \pm 10.1$ \\
\hline 8 & $A c$ & $\mathrm{H}$ & v & $\mathrm{F}$ & $\mathrm{N}$ & s & W & $\mathrm{E}$ & $\mathrm{E}$ & $\mathrm{Y}$ & L & $\mathrm{D}$ & w & V & & & & & & & $\mathrm{NH}_{2}$ & $62.4 \pm 9.9$ \\
\hline 18 & $A c$ & H & v & $\mathrm{F}$ & $\mathrm{k}$ & $\mathrm{s}$ & w & $\mathrm{K}^{*}$ & E & $\mathrm{Y}$ & L & $\mathrm{D}^{*}$ & w & v & $\mathrm{K}$ & K & $\mathrm{K}$ & $\mathrm{K}$ & $\mathrm{K}$ & $\mathrm{K}$ & $\mathrm{NH}_{2}$ & $0.175 \pm 0.04^{b}$ \\
\hline
\end{tabular}

Reversal of LDL uptake inhibition mediated by PCSK9 in HepG2 cells. a, \% LDL uptake at $10 \mu \mathrm{M}, \mathbf{b}, \mathrm{EC}_{50}$ $(\mu \mathrm{M})$

All peptides were able to reverse the LDL uptake inhibition mediated by PCSK9. The stapled peptides $\mathbf{3}$ and $\mathbf{4}$, and peptide $\mathbf{8}$ had a slightly higher affinity than Pep2-8 and their ability to restore LDL uptake was comparable to Pep2-8, ranging from $42.7 \%$ to $62.4 \%$ (Table 3 ). The peptide affinities for PCSK9 and the LDL uptake restoration were globally well-related. Peptide 1 with the highest affinity in this series $(1.6 \mu \mathrm{M})$ showed a $15 \%$ higher level of reversion of the LDL uptake inhibition (72.3\%) than Pep2-8. Remarkably, peptide 18 restored LDL uptake up to 100\% at $10 \mu \mathrm{M}$ and showed an $\mathrm{EC}_{50}$ of $0.175 \pm 0.04 \mu \mathrm{M}$. The presence of the lysine patch associated with hydrophobic residues at position 6,9 and 12 , could be suspected to induce pseudo-allergic 
response due to mast cell degranulation and histamine release in vivo. Therefore, chemokine release from LAD2 cell was used to estimate the potential risk of anaphylactic response with the lead peptide 18. ${ }^{52-54}$ The results were compared with those from Pep2-8, the stapled peptide 3 and substance $\mathrm{P}$ as positive control. As shown in Figure 5E, Pep2-8 and the stapled peptide 3 did not induce significant CCL3 release from LAD2 cells and the lead peptide $\mathbf{1 8}$ elicited only moderate release $\left(\mathrm{EC}_{50}>5 \mu \mathrm{M}, \mathrm{Emax}=116.7 \pm 15.5 \mathrm{pg} / \mathrm{mL}\right.$ at $5 \mu \mathrm{M} ; \mathrm{EC}_{50}>5 \mu \mathrm{M}, \mathrm{Emax}=716.6 \pm 13.5$ $\mathrm{pg} / \mathrm{mL}$ at $5 \mu \mathrm{M}$ and $\mathrm{EC}_{50}=2.2 \mu \mathrm{M}, \mathrm{Emax}=1483.2 \pm 346.2 \mathrm{pg} / \mathrm{mL}$ at $5 \mu \mathrm{M}$, respectively) compared to substance $\mathrm{P}\left(\mathrm{EC}_{50}=0.68 \mu \mathrm{M}, \mathrm{Emax}=29125.9 \pm 7223.3 \mathrm{pg} / \mathrm{mL}\right.$ at $\left.5 \mu \mathrm{M}\right)($ Figure 5).

\section{CONCLUSIONS}

We developed strong PCSK9 binders starting from the reference peptide Pep2-8, a competitive inhibitor of the PCSK9/LDLR interaction, previously found by phage-display. The most potent Pep2-8 analogs displayed a 1000-fold improvement of binding affinity to PCSK9 with $\mathrm{K}_{\mathrm{D}}$ values around 6-7 nM, and an about 35-fold enhancement of the LDL uptake compared to Pep2-8. We showed that targeting a proximal acidic patch at the PCSK9 surface by elongating Pep2-8 with a C-terminal six-lysine patch dramatically increased the affinity of the analogs for PCSK9 while only three lysine residues gave moderate increase in both binding affinity and LDL uptake restoration. Interestingly, the introduction of a staple between the positions 7 and 11 of Pep2-8 did not improve its affinity for PCSK9 (peptides 3 and 4), while the incorporation of either a lactam or a hydrocarbon bridge in combination with the six-lysine patch significantly increased the binding affinity (peptide 6). These results showed that the efficiency of such peptides may not be related to an increase of the helicity of the 6-19 region of Pep2-8 but to the substitution of the Asp11 residue, preventing undesirable intramolecular electrostatic interactions. Therefore, a high 
adaptability of the C-terminal lysine tail in this family of peptides was necessary to favor close contacts with the PCSK9 negatively charged residue patch at the PCSK9 surface. Importantly, the six-lysine-containing Pep2-8 derivatives allowed the identification of this patch as a promising target site to drastically improve the binding to PCSK9. Additionally, we showed that single mutations within the N-terminal strand allowed to further increase the analogs affinity for PCSK9. As expected, the high-affinity analogs efficiently restored the LDL-uptake of PCSK9 by HepG2 cells, up to an $\mathrm{EC}_{50}$ of $175 \mathrm{nM}$ (peptide 18). To the best of our knowledge, compound 18, combining stapled peptide and SIP technologies, is one of the most potent PCSK9 binders that restores LDL uptake in the HepG2 cellular assay. While this peptide has the activity and potency of a lead compound, further optimization is required for therapeutic application. As P18 caused a moderate effect on chemokine release, mast cell degranulation will be a parameter to be considered for further optimization by reducing for example the content of Lys residues at the C-terminal part of the peptide. Moreover, in order to circumvent the possible limitation of oral delivery of such peptides, different strategies ${ }^{55-57}$ could be considered for generating potential therapeutic candidate.

\section{EXPERIMENTAL SECTION}

\section{Pep2-8 analogs synthesis}

SPPS general procedure. The peptides were synthesized at the "Institut des Biomolécules Max Mousseron" (IBMM) in Montpellier using a standard Fmoc/tBu Solid Phase Peptide Synthesis (SPPS) protocol. ${ }^{58}$ The syntheses were performed on a 0.25 mmol scale using Fmoc-Rink amide AmphiSpheres ${ }^{\mathrm{TM}} 40 \mathrm{RAM}$ resin $(0.37 \mathrm{mmol} / \mathrm{g})$. They were carried out in syringes equipped with a PTFE frit to allow removal of the excess of solvents and reactants by filtration.

Procedure 1 - Anchoring on Rink-amide PS/PEG resin. Fmoc-Rink amide resin was conditioned for 10 min in DMF and submitted to the standard deprotection cycle, using a 
DMF/piperidine 80/20 v/v solution for 2x1 min. After washing steps, the first Fmoc protected amino acid was loaded onto the resin using a standard coupling cycle with HATU (5 eq.) as a coupling agent and DIEA (10 eq.) as base. The mixture was stirred in a $650 \mathrm{rpm}$ vortex for $10 \mathrm{~min}$ at room temperature. The resin was then washed twice with DMF and the coupling step was repeated. At the end of the second coupling, the resin was washed three times with DMF and twice with DCM. A capping was performed following Procedure 4.

Procedure 2 - Fmoc deprotection. Fmoc removal was achieved by treatment with a $20 \%$ piperidine/DMF solution stirred for $1 \mathrm{~min}$. The solution was removed by filtration under vacuum, and the deprotection step was repeated to avoid incomplete deprotection. The solution was filtered, and the resin was washed three times with DMF.

Procedure 3 - Coupling steps. The Fmoc protected amino acid solution (0,5 M in DMF, 5 eq.) was introduced in the syringe followed by the addition of 10 eq. of DIEA and 5 eq. of HATU $(0,5$ M) and the mixture was stirred in a $650 \mathrm{rpm}$ vortex for $3 \mathrm{~min}$ at room temperature. The resin was then washed twice with DMF and the coupling step was repeated. At the end of the second coupling, the resin was washed three times with DMF.

Procedure 4 - Capping. Capping was performed with acetic anhydride to stop the elongation of deleted peptides. After the coupling step washings, the resin was swollen with DCM for 5 min. The DCM was then removed and a 50/50 DCM/acetic anhydride solution (v/v) is added. The mixture was stirred for $10 \mathrm{~min}$. The capping solution was then removed by filtration. The resin was washed three times with DCM, then swollen in DMF for 5 min. The DMF was removed by filtration and the resin washed twice with DMF. This procedure was also used for the final acetylation of the peptides.

Procedure 5 - Final cleavage. Oligomers were cleaved from the resin by treatment with a $50 \mathrm{ml}$ TFA/TIS/ $\mathrm{H}_{2} \mathrm{O}(95 / 2.5 / 2.5)$ solution for $2 \mathrm{~h}$. After removal of the resin by filtration, it was washed three times with fresh cleavage cocktail. The TFA filtrates were gathered and concentrated under reduced pressure. Compounds were precipitated by addition of $50 \mathrm{ml}$ of diethyl ether and recovered after centrifugation. Finally, the peptides were dissolved in an acetonitrile/water 50/50 solution containing $0.1 \%$ TFA and freeze dried.

Compounds purification. All crude compounds were purified by preparative HPLC (Gilson PLC 2250 apparatus) on a C18 reversed-phase column (C18 Deltapak column, $100 \mathrm{~mm}$ x 40 mm, 15 $\mu \mathrm{m}, 100 \AA$ ) at a flow rate of $50 \mathrm{~mL} / \mathrm{min}$ of a $\mathrm{H}_{2} \mathrm{O}+0.1 \%$ TFA and $\mathrm{CH}_{3} \mathrm{CN}+0.1 \%$ TFA mixture 
in gradient mode with UV detection at $214 \mathrm{~nm}$. Fractions containing the pure product were collected and freeze dried. All compounds were obtained with purity >95\% (HPLC).

SPR measurements. Initial experiments were performed on a Biacore T100 or T200 (GE Healthcare) using identical protocols. Characterization of high affinity peptides was performed on a Biacore $8 \mathrm{~K}$ under similar conditions. PCSK9 Capture Buffer was comprised of $25 \mathrm{mM}$ Tris- $\mathrm{HCl}$ (Invitrogen), $5 \mathrm{mM} \mathrm{CaCl}_{2}$ (Sigma), $100 \mathrm{mM} \mathrm{NaCl}$ (Sigma), 0.01\% P20 (GE Healthcare), pH 7.5, and filtered through a 0.2 um filter. PCSK9 Running Buffer is identical to Capture buffer with the addition of DMSO (Sigma) to 5\%. Biacore instruments were cleaned prior to each experiment using the Desorb procedure (GE Healthcare) using standard reagents, followed by another Desorb using 50\% DMSO/water (Desorb 1), and 10\% DMSO/water (Desorb 2). Temperature for all procedures was set to $25^{\circ} \mathrm{C}$. Instrument with a maintenance chip docked was primed with water twice, then primed with Capture Buffer. A fresh NTA chip (GE Healthcare) was brought to room temperature prior to opening, then docked into the instrument. A final prime with Capture Buffer was performed. Capture was accomplished by the following series of injections. 1) $60 \mathrm{sec}$ injection of $350 \mathrm{mM}$ EDTA (Regeneration) followed by $60 \mathrm{sec}$ Capture Buffer at $100 \mu \mathrm{L} / \mathrm{min}$ over both active and reference flow cells. 2) $120 \mathrm{sec}$ injection of $0.5 \mathrm{mM} \mathrm{NiCl}_{2}$ (GE Healthcare) followed by $60 \mathrm{sec}$ Capture Buffer at $10 \mu \mathrm{L} / \mathrm{min}$ over both active and reference flow cells. 3) $300 \mathrm{sec}$ injection of 0.05 M NHS/0.2 M EDC (Amine Coupling Kit, GE Healthcare) mixed immediately prior to injection, followed by various times of $14 \mu \mathrm{g} / \mathrm{mL}$ His-PCSK9 (Human PCSK9, His Tag from AcroBiosystems ref. PC9-H5223, or Gln 31-Gln 692 recombinant protein (Accession \# Q8NBP7-1) + poly-histidine Tag in C-Termexpressed in HEK293 cells and produced internally) in Capture Buffer at $5 \mu \mathrm{L} / \mathrm{min}$ over only the active flow cell. These experimental conditions resulted in stable capture of approximately 1000-4000 RU of His-PCSK9, and thus a theoretical peptide binding Rmax of 20-80 RU (lower densities were used for kinetic analyses). Instrument was primed with Running Buffer and let run in standby mode for approximately $1 \mathrm{~h}$ prior to starting method. Peptides were prepared by Sanofi Compound Logistics as $10 \mathrm{mM}$ stocks in 100\% DMSO. These stocks were used to prepare various concentrations using an acoustic liquid dispenser (ECHO 550, Labcyte Inc.). Typically, $30 \mathrm{~nL}$ of compound in DMSO were dispensed into each well, then resuspended with $100 \mu \mathrm{L}$ of Running Buffer, mixed well and the plate was sealed and spun briefly to remove bubbles. A 6-step solvent correction was applied per recommended protocol (GE Healthcare). Samples were injected over active and reference flow cells for $60 \mathrm{sec}$ 
followed by a dissociation for $120 \mathrm{sec}$. Multi-cycle affinity and kinetic analyses were performed using Biacore T200 Evaluation Software (v 2.0) or Biacore Insight Evaluation Software (v 2.0). Binding responses (sensorgrams) were "double-referenced" - the binding response from the reference flow cell was subtracted from the active response, and a buffer injection over the active surface was also subtracted. Steady-state affinity analysis was performed using a double-reference response at equilibrium for each concentration fit to a 4-parameter model within the evaluation software. Kinetic analysis was performed using a 1:1 binding model within the evaluation software.

Circular dichroism. CD experiments were performed using a Jasco J815 spectropolarimeter. Peptides were dissolved at $100 \mu \mathrm{M}$, in phosphate buffer at $\mathrm{pH}$ 6.5. Concentrations were checked measuring the absorbance at $280 \mathrm{~nm}\left(\mathrm{~A}_{280}\right)$. Spectra were obtained using a $1 \mathrm{~mm}$ path length $\mathrm{CD}$ cuvette, at $20^{\circ} \mathrm{C}$, over a wavelength range of 190-260 $\mathrm{nm}$. Continuous scanning mode was used, with a response of $1.0 \mathrm{~s}$ with $0.1 \mathrm{~nm}$ steps and a bandwidth of $2 \mathrm{~nm}$. The signal-to-noise ratio was improved by acquiring each spectrum over an average of three scans. The baseline was corrected by subtracting the background from the sample spectrum.

\section{NMR and molecular modelling}

NMR experiments. NMR samples containing $2 \mathrm{mM}$ of peptides were dissolved in phosphate buffer, pH 6.5. All spectra were recorded on a Bruker Avance 600 AVANCE III spectrometer equipped with a $5 \mathrm{~mm}$ triple-resonance cryoprobe $\left({ }^{1} \mathrm{H},{ }^{13} \mathrm{C},{ }^{15} \mathrm{~N}\right)$ at the "Laboratoire de Mesures Physiques (LMP)" of the University of Montpellier (UM). Homonuclear 2D spectra DQF-COSY, TOCSY (DIPSI2), ROESY and NOESY were typically recorded in the phase-sensitive mode using the States-TPPI method as data matrices of 400 real $(\mathrm{t} 1) \times 2048(\mathrm{t} 2)$ complex data points; 8-40 scans per $\mathrm{t} 1$ increment with $1.2 \mathrm{~s}$ recovery delay and spectral width of $7210 \mathrm{~Hz}$ in both dimensions were used. The mixing times were $80 \mathrm{~ms}$ for TOCSY and $120 \mathrm{~ms}$ for the ROESY experiments. Spectra were processed with Topspin (Bruker Biospin) and visualized with Topspin or

NMRview $^{59}$ on a Linux station. Matrices were zero-filled to 1024 (t1) x 2048 (t2) points after apodization by shifted sine-square multiplication and linear prediction in the F1 domain. Chemical shifts were referenced to trimethylsilylpropanoic acid (TSP). 
Structure calculations. ${ }^{1} \mathrm{H}$ chemical shifts were assigned according to classical procedures. NOE cross-peaks were integrated and assigned within the NMRView software. ${ }^{59}$ The volumes of NOE peaks between methylene pair protons were used as reference of $1.8 \AA$. The lower bound for all restraints was fixed at $1.8 \AA$ and upper bounds at 2.7, 3.3 and $5.0 \AA$, for strong, medium and weak correlations, respectively. Pseudo-atom corrections of the upper bounds were applied for unresolved aromatic, methylene and methyl proton signals as described previously. ${ }^{60}$ Structure calculations were performed with AMBER $16^{61}$ in two stages: cooking, simulated annealing using Generalized Born implicit solvent model. The cooking stage was performed at $1000 \mathrm{~K}$ to generate 100 initial random structures. Simulated annealing calculations were carried during 20 ps (20000 steps, 1 fs long). First, the temperature was risen quickly and was maintained at $1000 \mathrm{~K}$ for the first 5000 steps, then the system was cooled gradually from $1000 \mathrm{~K}$ to $100 \mathrm{~K}$ from step 5001 to 18000 , and finally the temperature was brought to $0^{\circ} \mathrm{K}$ for the 2000 remaining steps. For the 3000 first steps, the force constant of the distance restraints was increased gradually from $2.0 \mathrm{kcal}^{\mathrm{mol}}{ }^{-}$ ${ }^{1} . \AA$ to $20 \mathrm{kcal} \mathrm{mol}^{-1}$. $\AA$. For the rest of the simulation (step 3001 to 20000), the force constant was kept at $20 \mathrm{kcal} . \mathrm{mol}^{-1}$. $\AA$. The 20 lowest energy structures with no violations $>0.3 \AA$ were considered representative of the peptide structure. The representation and quantitative analysis were carried out using MOLMOL ${ }^{62}$ and PyMOL (Delano Scientific).

Molecular Dynamics Simulations. Molecular modelling studies were performed using Schrodinger tools: Maestro, Macromodel (Schrödinger Release 2019-4: Maestro and Macromodel, Schrödinger, LLC, New York, NY, 2019) and Desmond ${ }^{63}$ (Schrödinger Release 2019-3: Desmond Molecular Dynamics System, D. E. Shaw Research, New York, NY, 2019. Maestro-Desmond Interoperability Tools, Schrödinger, New York, NY, 2019) with OPLS3 force field ${ }^{64}$. MD simulations used the crystallographic structure of $\triangle$ CRD-PCSK9 in complex with Pep2-8 (PDB code: 4NMX). Lysine patches have been added in fully extended conformation. Resulting structures have been energy-minimized with Macromodel and then submitted to MD as starting point in two different simulations to study Peptides $\mathbf{1}$ and $\mathbf{2}$ in complex with PCSK9.

Peptides 1 and 2 have been included in a cubic water box, $50 \AA \AA$ side length, SPC solvent model, $\mathrm{NaCl}$ concentration $0.15 \mathrm{M}$. Each system has been then submitted to $200 \mathrm{~ns}$ MD simulation after standard relaxation protocol, with 2 fs timestep, NPT ensemble, target temperature $298 \mathrm{~K}$. After controlling that each peptide was in a stable conformation at the end of the simulation, the final 
structures have been placed in complex with $\triangle$ CRD-PCSK9, with a positioning similar to the one

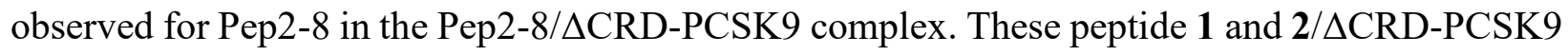
complexes have been included in a cubic water box, SPC solvent model, $\mathrm{NaCl}$ concentration 0.15 M. Each system has been then submitted to 200 ns MD simulation after standard relaxation protocol, with 2 fs timestep, NPT ensemble, target temperature $298 \mathrm{~K}$. The trajectories were analysed using VMD software (Visual Molecular Dynamics). ${ }^{65}$ Electrostatic interactions were analysed using the 'Salt Bridges Plugin' in VMD. We monitored the distances (in Å) between any of the oxygen atoms of acidic residues and the nitrogen atoms of basic residues, and the cation- $\pi$ interaction between the Lys12 protonated amino group and the Trp16 indole ring measuring the distance $\mathrm{dN} \zeta-\mathrm{C} \varepsilon 2$ (in $\AA$ ) in Pep2-8.

Toxicity Assays. The cytotoxicity was determined at the "Institut de Génomique Fonctionnelle" in Montpellier. In brief, HepG2 cells (ATCC® HB-8065) were seeded at 2000 cells/well in clear, flat-bottomed 96-well plates (Costar), $24 \mathrm{~h}$ before treatment. After being washed, $200 \mu \mathrm{L}$ of culture medium that contained the compounds at different concentrations $(0.4,1.1,3.3$ and $10 \mu \mathrm{M}$ in DMEM) was added to the wells and incubated at $37^{\circ} \mathrm{C}$ for $48 \mathrm{~h}$. The cytotoxicity assay was performed by the addition of $20 \mu \mathrm{l}$ of SRB solution ( $50 \mu \mathrm{L}$ at $0.4 \%$ in $1 \%$ acetic acid solution) into each well and cells were incubated at $37^{\circ} \mathrm{C}$ for another $30 \mathrm{~min}$. The medium was removed and 100 $\mu \mathrm{l}$ of Tris base $10 \mathrm{mM}$ were added into each well. The plate was gently rotated on an orbital shaker for $5 \mathrm{~min}$ to completely dissolve the precipitate. The absorbance was detected at $560 \mathrm{~nm}$ with a Microplate Reader (Multiskan FC, ThermoFisher Scientific, France). The results obtained from triplicate wells were averaged and normalized to the value obtained from the non-treated cells.

LDL uptake assay. HepG2 Cells were seeded in 96 well plate format at 40000 cells/well. $100 \mu \mathrm{L}$ of cell solution was gently mixed, seeded and incubated at $37^{\circ} \mathrm{C} / 5 \% \mathrm{CO}_{2}$. At $\mathrm{J} 0+24 \mathrm{~h}$, cells were washed and incubated $24 \mathrm{~h}$ with DMEM supplemented with 5\% LPDS, glutamax (1x) (fetal calf LipoProtein Deficient Serum, Sigma-Aldrich), pyruvate (1x) and antiA (1x) (100 $\mu \mathrm{L})$ at $37^{\circ} \mathrm{C} / 5 \%$ $\mathrm{CO}_{2}$. At J0 +48 h, PCSK9 (Human PCSK9, His Tag from AcroBiosystems ref. PC9-H5223. Gln 31 - Gln 692 recombinant protein (Accession \# Q8NBP7-1) + poly-histidine Tag in C-Term. Expressed in HEK293 cells and produced internally) (20-50 nM) was preincubated 30 to $60 \mathrm{~min}$ at room temperature with or without test compounds at different concentrations in DMEM supplemented with $0.1 \%$ - 5\% LPDS, glutamax (1x), pyruvate (1x), and antiA (1x). Test 
compounds, stored in DMSO, were added to achieve serial dilutions from $10 \mu \mathrm{M}$ to $0.0001 \mu \mathrm{M}$ in a total of $0.1 \%$ DMSO. Medium was removed and cells were incubated $2 \mathrm{~h}$ with medium containing PCSK $9+/$ - compounds $(100 \mu \mathrm{L})$ at $37^{\circ} \mathrm{C} / 5 \% \mathrm{CO}_{2}$. Then 2 or $10 \mu \mathrm{L}$ of LDL-BODIPY (Invitrogen, Thermo Fischer Scientific) solution was added in each well (dilution 1/50 or 1/11) to give a final concentration at $10 \mu \mathrm{g} / \mathrm{mL}$ and cells were incubated $4 \mathrm{~h}$ at $37^{\circ} \mathrm{C} / 5 \% \mathrm{CO}_{2}$. Medium was removed and cells were washed twice with PBS (1x). $100 \mu \mathrm{L}$ PBS was added and fluorescence and cell morphology were measured with Saphire II or Fluorimeter (bottom read, Flex station, Molecular Device) (excitation (abs) 480nm and emission 520nm) and InCell2000 or equivalent material. Results were expressed as \% of the maximum LDL BODIPY incorporation. $\mathrm{EC}_{50}$ values and Hill slope were calculated using the Biospeed non-linear method.

LAD2 cell assay. The human mast cell line, LAD2 (AGB n ${ }^{\circ}$ L63-CH20) was used under license from the National Institutes of Health (NIH), 5601 Fishers Lane, R-2G58, MSC9804 Rockville, MD 20852-9804. LAD2 cells were washed with StemPro 34 medium (GIBCO, \#10640-019), suspended at $0.2 \times 10^{6}$ cells per well, and then exposed to test peptides or Substance P (Cayman, \#24035) as positive control. CCL3 was used as a marker of LAD2 activation. ${ }^{54}$ Test peptides were dissolved in $100 \%$ DMSO at $10 \mathrm{mM}$ (stock solution), then to intermediate dilution in 5\% DMSO. $20 \mu \mathrm{l}$ of each working dilution were used in assay (200 $\mu \mathrm{L}$ final) to have $0.5 \%$ DMSO. Test peptides were added to wells in triplicate over a range of 7 concentrations $(20 \mu 1 /$ well; $5 \mathrm{nM}-5$ $\mu \mathrm{M}$ ), and incubated at $37^{\circ} \mathrm{C}$. At 2 hours, supernatant was collected and frozen at $-80^{\circ} \mathrm{C}$ until used for analysis. CCL3 levels were measured using Human CCL3/MIP-1 alpha Magnetic Luminex kit (R\&D, \#LUHM270) according to manufacturer's protocol. A full dose response curve from $5 \mathrm{nM}$ to $5 \mu \mathrm{M}$ was performed in triplicate. $\mathrm{EC}_{50}$ values and the maximal release of CCL3 at $5 \mu \mathrm{M}$ (Emax) were determined with SAS procedure NLIN in SAS system release 9.4 under Unix via Biost@tSPEED-LTS v2.3 internal software using the 4-parameter logistic model according to Ratkowsky and Reedy, $\mathrm{Y}=\mathrm{A}+\left[\mathrm{C} /\left(1+\exp \left(-\mathrm{B}^{*}(\log (\mathrm{X})-\mathrm{M})\right)\right)\right]{ }^{66}$ The parameters $\mathrm{A}$ and $(\mathrm{A}+\mathrm{C})$ are the lower and upper asymptotes, $\mathrm{B}$ is the slope of the curve at the inflexion point, and $\mathrm{M}$ parameter is the logarithm of the concentration estimated at the inflexion point. 


\section{ASSOCIATED CONTENT}

\section{Supporting Information.}

Pep2-8 structure, SPR data, $K_{D}$ values of all the peptides obtained by the Ala scanning of Pep2-

8 and the truncated stapled peptide S14, NMR data: ${ }^{1} \mathrm{H}$ NMR chemical shifts for Pep2-8, 1, 2, 3, 6, 7, 8, 18 in PBS $\left(10 \% \mathrm{D}_{2} \mathrm{O}\right)$, characteristic NOEs of the aromatic patch for Pep2-8, 7 and $\mathbf{8} ;{ }^{1} \mathrm{H}$ NMR spectra of peptides $\mathbf{1}, \mathbf{2}, \mathbf{3}, \mathbf{7}$ and $\mathbf{8}$, Superimposition of COSY, TOCSY and NOESY spectra of peptides 6 and 18 in PBS $\left(10 \% \mathrm{D}_{2} \mathrm{O}\right), \mathrm{CD}$ spectra, MD simulation and LCMS spectra.

Representative MD structures of peptide 1 and 2 in complexe with PCSK9 (Figure 4) are provided: Fig4A_peptide 1.pdb, Fig4B_peptide 2.pdb, Fig4C_peptide 2.pdb

Molecular formula strings for final compounds are provided.

\section{AUTHOR INFORMATION}

\section{Corresponding Author}

Muriel Amblard: muriel.amblard@umontpellier.fr

Baptiste Legrand: baptiste.legrand@umontpellier.fr

Sergio Mallart: sergio.mallart@sanofi.com

\section{Author Contributions}

M.A., B.L., S.M., G.M., G.L. O.D. conceived and supervised the study; B.L., C.M. conducted and supervised CD, NMR and MD simulations studies; K.B., P.V. performed peptide syntheses and CD experiments, J.D.S. performed SPR experiments and analyzed the data; P.P., J.C.L. performed LDL uptake experiments and analyzed the data. M.A., B.L. K.B. analyzed all the data and wrote 
the manuscript with contributions from all authors. All authors have read and agreed to the published version of the manuscript.

\section{Funding Sources}

This work was co-funded by Sanofi R\&D and ANRT (Association Nationale de la Recherche et de la Technologie). K.B. was supported by a doctoral CIFRE fellowship from Sanofi R\&D.

\section{ACKNOWLEDGMENT}

We thank LMP (Laboratoire de Mesures Physiques, UM Montpellier) for providing access to CD and NMR spectroscopy facilities, Janice Villali for running one of the SPR experiments and Dr. J.M. Pascussi for the toxicity assays. Joo-Hye Song, Yui-His Wang and Andrew Smith are deeply acknowledged for the evaluation of peptides in LAD2 cell assay.

\section{ABBREVIATIONS}

ASCVD, atherosclerotic cardiovascular diseases; BODIPY, boron-dipyrromethene; COSY, correlation spectroscopy; CD, circular dichroism; CVD, cardiovascular diseases; DCM, dichloromethane; DIEA, N,N-diisopropylethylamine; DMEM, Dulbecco's modified eagle medium; DMF, dimethylformamide; DMSO, dimethyl sulfoxide; $\mathrm{EC}_{50}$, half maximal effective

concentration; EDC, 1-Ethyl-3-(3-dimethylaminopropyl)carbodiimide; $\quad$ EDTA, ethylenediaminetetraacetic acid; EGF-A, epidermal growth factor precursor homology domain A; EKO, exploring key orientations; Fmoc, 9-fluorenylmethoxycarbonyl protecting group; HATU, hexafluorophosphate azabenzotriazole tetramethyl uronium; $\mathrm{K}_{\mathrm{D}}$, affinity constant; $\mathrm{IC}_{50}$, half maximal inhibitory concentration; LDL, low density lipoprotein; LDL-BODIPY, Low density lipoprotein from human plasma Molecular Probes TM; LDLc, low density lipoprotein cholesterol; LDLR, low density lipoprotein receptor; LPDS, lipoprotein deficient serum; mAb, monoclonal 
antibody; MD, molecular dynamics; MRE, mean residual ellipticity; $\mu \mathrm{M}$, micromolar; $\mathrm{nM}$, nanomolar; NHS, N-hydroxysuccinimide; NMR, nuclear magnetic resonance; NOE, nuclear Overhauser effect; NOESY, nuclear Overhauser effect spectroscopy; NTA, nitrilotriacetic acid; PBS, phosphate-buffered saline; PCSK9, proprotein convertase subtilisin kexin type 9 ; PDB, protein data bank; PEG, polyethylene glycol; PPI, protein-protein interaction; PS, polystyrene; PTFE, polytetrafluoroethylene; RAM, rink amide; RMSD, root mean square deviation; $\mathrm{S}_{5}$, (S)-2(4'pentenyl)-alanine; ROESY, rotating frame Overhauser enhancement spectroscopy; SIP, structure-inducing probes; siRNA, small interfering ribonucleic acid; SPPS, solid phase peptide synthesis; SPR, surface plasmon resonance; SRB, sulforhodamine B; tBu, tert-butoxycarbonyl protecting group; TFA, trifluoroacetic acid; TIS, triisopropylsilane; TOCSY, total correlation spectroscopy; TSP, trimethylsilylpropanoic acid.

\section{REFERENCES}

(1) Yusuf, S.; Hawken, S.; Ôunpuu, S.; Dans, T.; Avezum, A.; Lanas, F.; McQueen, M.; Budaj, A.; Pais, P.; Varigos, J.; Lisheng, L. Effect of Potentially Modifiable Risk Factors Associated with Myocardial Infarction in 52 Countries (the INTERHEART Study): Case-Control Study. The Lancet 2004, 364 (9438), 937-952. https://doi.org/10.1016/S0140-6736(04)17018-9.

(2) Goldstein, J. L.; Brown, M. S. A Century of Cholesterol and Coronaries: From Plaques to Genes to Statins. Cell 2015, 161 (1), 161-172. https://doi.org/10.1016/j.cell.2015.01.036.

(3) Ference, B. A.; Ginsberg, H. N.; Graham, I.; Ray, K. K.; Packard, C. J.; Bruckert, E.; Hegele, R. A.; Krauss, R. M.; Raal, F. J.; Schunkert, H.; Watts, G. F.; Borén, J.; Fazio, S.; Horton, J. D.; Masana, L.; Nicholls, S. J.; Nordestgaard, B. G.; van de Sluis, B.; Taskinen, M.-R.; Tokgözoğlu, L.; Landmesser, U.; Laufs, U.; Wiklund, O.; Stock, J. K.; Chapman, M. J.; Catapano, 
A. L. Low-Density Lipoproteins Cause Atherosclerotic Cardiovascular Disease. 1. Evidence from Genetic, Epidemiologic, and Clinical Studies. A Consensus Statement from the European Atherosclerosis Society Consensus Panel. Eur Heart $J$ 2017, 38 (32), 2459-2472. https://doi.org/10.1093/eurheartj/ehx144.

(4) Bruckert, E.; Hayem, G.; Dejager, S.; Yau, C.; Bégaud, B. Mild to Moderate Muscular Symptoms with High-Dosage Statin Therapy in Hyperlipidemic Patients - The PRIMO Study. Cardiovascular Drugs and Therapy 2005, 19 (6), 403-414. https://doi.org/10.1007/s10557-0055686-z.

(5) Mancini, G. B. J.; Tashakkor, A. Y.; Baker, S.; Bergeron, J.; Fitchett, D.; Frohlich, J.;

Genest, J.; Gupta, M.; Hegele, R. A.; Ng, D. S.; Pearson, G. J.; Pope, J. Diagnosis, Prevention, and Management of Statin Adverse Effects and Intolerance: Canadian Working Group Consensus Update. Canadian Journal of Cardiology 2013, 29 (12), 1553-1568. https://doi.org/10.1016/j.cjca.2013.09.023.

(6) Keen, H. I.; Krishnarajah, J.; Bates, T. R.; Watts, G. F. Statin Myopathy: The Fly in the Ointment for the Prevention of Cardiovascular Disease in the 21st Century? Expert Opinion on Drug Safety 2014, 13 (9), 1227-1239. https://doi.org/10.1517/14740338.2014.937422.

(7) Joy, T. R.; Hegele, R. A. Narrative Review: Statin-Related Myopathy. Ann Intern Med 2009, 150 (12), 858-868. https://doi.org/10.7326/0003-4819-150-12-200906160-00009.

(8) Abifadel, M.; Varret, M.; Rabès, J.-P.; Allard, D.; Ouguerram, K.; Devillers, M.; Cruaud, C.; Benjannet, S.; Wickham, L.; Erlich, D.; Derré, A.; Villéger, L.; Farnier, M.; Beucler, I.; Bruckert, E.; Chambaz, J.; Chanu, B.; Lecerf, J.-M.; Luc, G.; Moulin, P.; Weissenbach, J.; Prat, A.; Krempf, M.; Junien, C.; Seidah, N. G.; Boileau, C. Mutations in PCSK9 Cause Autosomal 
Dominant Hypercholesterolemia. Nature Genetics 2003, $34 \quad$ (2), 154-156. https://doi.org/10.1038/ng1161.

(9) Maxwell, K. N.; Breslow, J. L. Adenoviral-Mediated Expression of Pcsk9 in Mice Results in a Low-Density Lipoprotein Receptor Knockout Phenotype. Proceedings of the National Academy of Sciences 2004, 101 (18), 7100-7105. https://doi.org/10.1073/pnas.0402133101.

(10) Benjannet, S.; Rhainds, D.; Essalmani, R.; Mayne, J.; Wickham, L.; Jin, W.; Asselin, M.C.; Hamelin, J.; Varret, M.; Allard, D.; Trillard, M.; Abifadel, M.; Tebon, A.; Attie, A. D.; Rader, D. J.; Boileau, C.; Brissette, L.; Chrétien, M.; Prat, A.; Seidah, N. G. NARC-1/PCSK9 and Its Natural Mutants: Zymogen Cleavage And Effects On The Low Density Lipoprotein (LDL) Receptor And LDL Cholesterol. Journal of Biological Chemistry 2004, 279 (47), 48865-48875. https://doi.org/10.1074/jbc.M409699200.

(11) Rashid, S.; Curtis, D. E.; Garuti, R.; Anderson, N. N.; Bashmakov, Y.; Ho, Y. K.; Hammer, R. E.; Moon, Y.-A.; Horton, J. D. Decreased Plasma Cholesterol and Hypersensitivity to Statins in Mice Lacking Pcsk9. Proceedings of the National Academy of Sciences 2005, 102 (15), 53745379. https://doi.org/10.1073/pnas.0501652102.

(12) Cohen, J.; Pertsemlidis, A.; Kotowski, I. K.; Graham, R.; Garcia, C. K.; Hobbs, H. H. Low LDL Cholesterol in Individuals of African Descent Resulting from Frequent Nonsense Mutations in PCSK9. Nature Genetics 2005, 37 (2), 161-165. https://doi.org/10.1038/ng1509.

(13) Lagace, T. A.; Curtis, D. E.; Garuti, R.; McNutt, M. C.; Park, S. W.; Prather, H. B.; Anderson, N. N.; Ho, Y. K.; Hammer, R. E.; Horton, J. D. Secreted PCSK9 Decreases the Number of LDL Receptors in Hepatocytes and Inlivers of Parabiotic Mice. Journal of Clinical Investigation 2006, 116 (11), 2995-3005. https://doi.org/10.1172/JCI29383. 
(14) Yan, W.; Zhao-Peng, L. PCSK9 Inhibitors: Novel Therapeutic Strategies for Lowering LDLCholesterol. Mini-Reviews in Medicinal Chemistry 2019, 19 (2), 165-176.

(15) Lavecchia, A.; Cerchia, C. Recent Advances in Developing PCSK9 Inhibitors for LipidLowering Therapy. Future Medicinal Chemistry 2019, $11 \quad$ (5), 423-441. https://doi.org/10.4155/fmc-2018-0294.

(16) Xu, S.; Luo, S.; Zhu, Z.; Xu, J. Small Molecules as Inhibitors of PCSK9: Current Status and Future Challenges. European Journal of Medicinal Chemistry 2019, 162, 212-233. https://doi.org/10.1016/j.ejmech.2018.11.011.

(17) Sabatine, M. S.; Giugliano, R. P.; Keech, A. C.; Honarpour, N.; Wiviott, S. D.; Murphy, S. A.; Kuder, J. F.; Wang, H.; Liu, T.; Wasserman, S. M.; Sever, P. S.; Pedersen, T. R. Evolocumab and Clinical Outcomes in Patients with Cardiovascular Disease. New England Journal of Medicine 2017, 376 (18), 1713-1722. https://doi.org/10.1056/NEJMoa1615664.

(18) Schwartz, G. G.; Steg, P. G.; Szarek, M.; Bhatt, D. L.; Bittner, V. A.; Diaz, R.; Edelberg, J. M.; Goodman, S. G.; Hanotin, C.; Harrington, R. A.; Jukema, J. W.; Lecorps, G.; Mahaffey, K. W.; Moryusef, A.; Pordy, R.; Quintero, K.; Roe, M. T.; Sasiela, W. J.; Tamby, J.-F.; Tricoci, P.; White, H. D.; Zeiher, A. M. Alirocumab and Cardiovascular Outcomes after Acute Coronary Syndrome. N Engl J Med 2018, 379 (22), 2097-2107. https://doi.org/10.1056/NEJMoa1801174.

(19) Dyrbuś, K.; Gąsior, M.; Penson, P.; Ray, K. K.; Banach, M. Inclisiran-New Hope in the Management of Lipid Disorders? Journal of Clinical Lipidology 2020, 14 (1), 16-27. https://doi.org/10.1016/j.jacl.2019.11.001. 
(20) Nishikido, T.; Ray, K. K. Non-Antibody Approaches to Proprotein Convertase Subtilisin Kexin 9 Inhibition: SiRNA, Antisense Oligonucleotides, Adnectins, Vaccination, and New Attempts at Small-Molecule Inhibitors Based on New Discoveries. Front. Cardiovasc. Med. 2019, 5, 199. https://doi.org/10.3389/fcvm.2018.00199.

(21) Zhang, D.-W.; Lagace, T. A.; Garuti, R.; Zhao, Z.; McDonald, M.; Horton, J. D.; Cohen, J. C.; Hobbs, H. H. Binding of Proprotein Convertase Subtilisin/Kexin Type 9 to Epidermal Growth Factor-like Repeat A of Low Density Lipoprotein Receptor Decreases Receptor Recycling and Increases Degradation. J. Biol. Chem. 2007, 282 (25), 18602-18612. https://doi.org/10.1074/jbc.M702027200.

(22) Kwon, H. J.; Lagace, T. A.; McNutt, M. C.; Horton, J. D.; Deisenhofer, J. Molecular Basis for LDL Receptor Recognition by PCSK9. Proceedings of the National Academy of Sciences $\mathbf{2 0 0 8}$, 105 (6), 1820-1825. https://doi.org/10.1073/pnas.0712064105.

(23) Bottomley, M. J.; Cirillo, A.; Orsatti, L.; Ruggeri, L.; Fisher, T. S.; Santoro, J. C.; Cummings, R. T.; Cubbon, R. M.; Lo Surdo, P.; Calzetta, A.; Noto, A.; Baysarowich, J.; Mattu, M.; Talamo, F.; De Francesco, R.; Sparrow, C. P.; Sitlani, A.; Carfi, A. Structural and Biochemical Characterization of the Wild Type PCSK9-EGF(AB) Complex and Natural Familial Hypercholesterolemia Mutants. J. Biol. Chem. 2009, 284 (2), 1313-1323. https://doi.org/10.1074/jbc.M808363200.

(24) Shan, L.; Pang, L.; Zhang, R.; Murgolo, N. J.; Lan, H.; Hedrick, J. A. PCSK9 Binds to Multiple Receptors and Can Be Functionally Inhibited by an EGF-A Peptide. Biochemical and $\begin{array}{llllll}\text { Biophysical Research } \quad \text { Communications 2008, } 375 & \text { (1), 69-73. }\end{array}$ https://doi.org/10.1016/j.bbrc.2008.07.106. 
(25) Schroeder, C. I.; Swedberg, J. E.; Withka, J. M.; Rosengren, K. J.; Akcan, M.; Clayton, D. J.; Daly, N. L.; Cheneval, O.; Borzilleri, K. A.; Griffor, M.; Stock, I.; Colless, B.; Walsh, P.; Sunderland, P.; Reyes, A.; Dullea, R.; Ammirati, M.; Liu, S.; McClure, K. F.; Tu, M.; Bhattacharya, S. K.; Liras, S.; Price, D. A.; Craik, D. J. Design and Synthesis of Truncated EGFA Peptides That Restore LDL-R Recycling in the Presence of PCSK9 In Vitro. Chemistry \& Biology 2014, 21 (2), 284-294. https://doi.org/10.1016/j.chembiol.2013.11.014.

(26) Lammi, C.; Zanoni, C.; Aiello, G.; Arnoldi, A.; Grazioso, G. Lupin Peptides Modulate the Protein-Protein Interaction of PCSK9 with the Low Density Lipoprotein Receptor in HepG2 Cells. Sci Rep 2016, 6 (1), 29931. https://doi.org/10.1038/srep29931.

(27) Zhang, Y.; Zhou, L.; Kong-Beltran, M.; Li, W.; Moran, P.; Wang, J.; Quan, C.; Tom, J.; Kolumam, G.; Elliott, J. M.; Skelton, N. J.; Peterson, A. S.; Kirchhofer, D. Calcium-Independent Inhibition of PCSK9 by Affinity-Improved Variants of the LDL Receptor EGF(A) Domain. Journal of Molecular Biology 2012, 422 (5), 685-696. https://doi.org/10.1016/j.jmb.2012.06.018.

(28) Zhang, Y.; Eigenbrot, C.; Zhou, L.; Shia, S.; Li, W.; Quan, C.; Tom, J.; Moran, P.; Di Lello, P.; Skelton, N. J.; Kong-Beltran, M.; Peterson, A.; Kirchhofer, D. Identification of a Small Peptide That Inhibits PCSK9 Protein Binding to the Low Density Lipoprotein Receptor. $J$ Biol Chem 2014, 289 (2), 942-955. https://doi.org/10.1074/jbc.M113.514067.

(29) Alleyne, C.; Amin, R. P.; Bhatt, B.; Bianchi, E.; Blain, J. C.; Boyer, N.; Branca, D.; Embrey, M. W.; Ha, S. N.; Jette, K.; Johns, D. G.; Kerekes, A. D.; Koeplinger, K. A.; LaPlaca, D.; Li, N.; Murphy, B.; Orth, P.; Ricardo, A.; Salowe, S.; Seyb, K.; Shahripour, A.; Stringer, J. R.; Sun, Y.; Tracy, R.; Wu, C.; Xiong, Y.; Youm, H.; Zokian, H. J.; Tucker, T. J. Series of Novel and Highly Potent Cyclic Peptide PCSK9 Inhibitors Derived from an MRNA Display Screen and 
Optimized via Structure-Based Design. J. Med. Chem. 2020, 63 (22), 13796-13824. https://doi.org/10.1021/acs.jmedchem.0c01084.

(30) Musunuru, K.; Chadwick, A. C.; Mizoguchi, T.; Garcia, S. P.; DeNizio, J. E.; Reiss, C. W.; Wang, K.; Iyer, S.; Dutta, C.; Clendaniel, V.; Amaonye, M.; Beach, A.; Berth, K.; Biswas, S.; Braun, M. C.; Chen, H.-M.; Colace, T. V.; Ganey, J. D.; Gangopadhyay, S. A.; Garrity, R.; Kasiewicz, L. N.; Lavoie, J.; Madsen, J. A.; Matsumoto, Y.; Mazzola, A. M.; Nasrullah, Y. S.; Nneji, J.; Ren, H.; Sanjeev, A.; Shay, M.; Stahley, M. R.; Fan, S. H. Y.; Tam, Y. K.; Gaudelli, N. M.; Ciaramella, G.; Stolz, L. E.; Malyala, P.; Cheng, C. J.; Rajeev, K. G.; Rohde, E.; Bellinger, A. M.; Kathiresan, S. In Vivo CRISPR Base Editing of PCSK9 Durably Lowers Cholesterol in Primates. Nature 2021, 593 (7859), 429-434. https://doi.org/10.1038/s41586-021-03534-y.

(31) Zhang, Y.; Ultsch, M.; Skelton, N. J.; Burdick, D. J.; Beresini, M. H.; Li, W.; KongBeltran, M.; Peterson, A.; Quinn, J.; Chiu, C.; Wu, Y.; Shia, S.; Moran, P.; Di Lello, P.; Eigenbrot, C.; Kirchhofer, D. Discovery of a Cryptic Peptide-Binding Site on PCSK9 and Design of Antagonists. Nat Struct Mol Biol 2017, 24 (10), 848-856. https://doi.org/10.1038/nsmb.3453.

(32) Burdick, D. J.; Skelton, N. J.; Ultsch, M.; Beresini, M. H.; Eigenbrot, C.; Li, W.; Zhang, Y.; Nguyen, H.; Kong-Beltran, M.; Quinn, J. G.; Kirchhofer, D. Design of Organo-Peptides As Bipartite PCSK9 Antagonists. ACS Chem. Biol. 2020, acschembio.9b00899. https://doi.org/10.1021/acschembio.9b00899.

(33) Tombling, B. J.; Lammi, C.; Lawrence, N.; Gilding, E. K.; Grazioso, G.; Craik, D. J.; Wang, C. K. Bioactive Cyclization Optimizes the Affinity of a Proprotein Convertase Subtilisin/Kexin Type 9 (PCSK9) Peptide Inhibitor. J. Med. Chem. 2021, 64 (5), 2523-2533. https://doi.org/10.1021/acs.jmedchem.0c01766. 
(34) Tombling, B.; Lammi, C.; Bollati, C.; Anoldi, A.; Craik, D.; Wang, C. Increased Valency Improves Inhibitory Activity of Peptides Targeting Proprotein Convertase Subtilisin/Kexin Type 9 (PCSK9). ChemBioChem 2021. https://doi.org/10.1002/cbic.202100103.

(35) Lammi, C.; Sgrignani, J.; Arnoldi, A.; Lesma, G.; Spatti, C.; Silvani, A.; Grazioso, G. Computationally Driven Structure Optimization, Synthesis, and Biological Evaluation of Imidazole-Based Proprotein Convertase Subtilisin/Kexin 9 (PCSK9) Inhibitors. J. Med. Chem. 2019, 62 (13), 6163-6174. https://doi.org/10.1021/acs.jmedchem.9b00402.

(36) Taechalertpaisarn, J.; Zhao, B.; Liang, X.; Burgess, K. Small Molecule Inhibitors of the PCSK9-LDLR Interaction. $J . \quad A m . \quad$ Chem. Soc. 2018, 140 (9), 3242-3249. https://doi.org/10.1021/jacs.7b09360.

(37) Chang, Y. S.; Graves, B.; Guerlavais, V.; Tovar, C.; Packman, K.; To, K.-H.; Olson, K. A.; Kesavan, K.; Gangurde, P.; Mukherjee, A.; Baker, T.; Darlak, K.; Elkin, C.; Filipovic, Z.; Qureshi, F. Z.; Cai, H.; Berry, P.; Feyfant, E.; Shi, X. E.; Horstick, J.; Annis, D. A.; Manning, A. M.; Fotouhi, N.; Nash, H.; Vassilev, L. T.; Sawyer, T. K. Stapled A-helical Peptide Drug Development: A Potent Dual Inhibitor of MDM2 and MDMX for P53-Dependent Cancer Therapy. Proceedings of the National Academy of Sciences 2013, 110 (36), E3445-E3454. https://doi.org/10.1073/pnas.1303002110.

(38) Bernal, F.; Tyler, A. F.; Korsmeyer, S. J.; Walensky, L. D.; Verdine, G. L. Reactivation of the P53 Tumor Suppressor Pathway by a Stapled P53 Peptide. Journal of the American Chemical Society 2007, 129 (9), 2456-2457. https://doi.org/10.1021/ja0693587. 
(39) Bernal, F.; Wade, M.; Godes, M.; Davis, T. N.; Whitehead, D. G.; Kung, A. L.; Wahl, G. M.; Walensky, L. D. A Stapled P53 Helix Overcomes HDMX-Mediated Suppression of P53. Cancer Cell 2010, 18 (5), 411-422. https://doi.org/10.1016/j.ccr.2010.10.024.

(40) Schafmeister, C. E.; Po, J.; Verdine, G. L. An All-Hydrocarbon Cross-Linking System for Enhancing the Helicity and Metabolic Stability of Peptides. Journal of the American Chemical Society 2000, 122 (24), 5891-5892. https://doi.org/10.1021/ja000563a.

(41) Shepherd, N. E.; Hoang, H. N.; Abbenante, G.; Fairlie, D. P. Single Turn Peptide Alpha Helices with Exceptional Stability in Water. Journal of the American Chemical Society 2005, 127 (9), 2974-2983. https://doi.org/10.1021/ja0456003.

(42) Larsen, B. D.; Holm, A.; Christensen, D. H.; Nielsen, O. F. Sequence Assisted Peptide Synthesis (SAPS): A Structural Evaluation of the Technology. In Peptides Frontiers of Peptide Science: Proceedings of the Fifteenth American Peptide Symposium June 14-19, 1997, Nashville, Tennessee, U.S.A.; Tam, J. P., Kaumaya, P. T. P., Eds.; American Peptide Symposia; Springer Netherlands: Dordrecht, 2002; pp 251-252. https://doi.org/10.1007/0-306-46862-X_102.

(43) Larsen, B. D.; Holm, A. Sequence-Assisted Peptide Synthesis (SAPS). The Journal of Peptide Research 1998, 52 (6), 470-476. https://doi.org/10.1111/j.1399-3011.1998.tb01251.x.

(44) Larsen, B. Pharmacologically Active Peptide Conjugates Having a Reduced Tendency Towards Enzymatic Hydrolysis. WO/1999/046283, 1999.

(45) Rizzi, A.; Rizzi, D.; Marzola, G.; Regoli, D.; Larsen, B. D.; Petersen, J. S.; Calo', G. Pharmacological Characterization of the Novel Nociceptin/Orphanin FQ Receptor Ligand, ZP120: 
In Vitro and in Vivo Studies in Mice. British Journal of Pharmacology 2002, 137 (3), 369-374. https://doi.org/10.1038/sj.bjp.0704894.

(46) Mallart, S.; Ingenito, R.; Bianchi, E.; Bresciani, A.; Esposito, S.; Gallo, M.; Magotti, P.; Monteagudo, E.; Orsatti, L.; Roversi, D.; Santoprete, A.; Tucci, F.; Veneziano, M.; Bartsch, R.; Boehm, C.; Brasseur, D.; Bruneau, P.; Corbier, A.; Froissant, J.; Gauzy-Lazo, L.; Gervat, V.; Marguet, F.; Menguy, I.; Minoletti, C.; Nicolas, M.-F.; Pasquier, O.; Poirier, B.; Raux, A.; Riva, L.; Janiak, P.; Strobel, H.; Duclos, O.; Illiano, S. Identification of Potent and Long-Acting SingleChain Peptide Mimetics of Human Relaxin-2 for Cardiovascular Diseases. J. Med. Chem. 2021, 64 (4), 2139-2150. https://doi.org/10.1021/acs.jmedchem.0c01533.

(47) Barnett, A. Lixisenatide: Evidence for Its Potential Use in the Treatment of Type 2 Diabetes. Core Evidence 2011, 6, 67-79. https://doi.org/10.2147/CE.S15525.

(48) Christensen, M.; Miossec, P.; Larsen, B. D.; Werner, U.; Knop, F. K. The Design and Discovery of Lixisenatide for the Treatment of Type 2 Diabetes Mellitus. Expert Opinion on Drug Discovery 2014, 9 (10), 1223-1251. https://doi.org/10.1517/17460441.2014.942638.

(49) Grieco, P.; Gitu, P. M.; Hruby, V. J. Preparation of "side-Chain-to-Side-Chain" Cyclic Peptides by Allyl and Alloc Strategy: Potential for Library Synthesis. J Pept Res 2001, 57 (3), 250-256. https://doi.org/10.1111/j.1399-3011.2001.00816.x.

(50) Blackwell, H. E.; Grubbs, R. H. Highly Efficient Synthesis of Covalently Cross-Linked Peptide Helices by Ring-Closing Metathesis. Angewandte Chemie International Edition 1998, 37 (23), 3281-3284. https://doi.org/10.1002/(SICI)1521-3773(19981217)37:23<3281::AIDANIE3281>3.0.CO;2-V. 
(51) Mirtič, A.; Grdadolnik, J. The Structure of Poly-1-Lysine in Different Solvents. Biophysical Chemistry 2013, 175-176, 47-53. https://doi.org/10.1016/j.bpc.2013.02.004.

(52) McNeil, B. D.; Pundir, P.; Meeker, S.; Han, L.; Undem, B. J.; Kulka, M.; Dong, X. Identification of a Mast-Cell-Specific Receptor Crucial for Pseudo-Allergic Drug Reactions. Nature 2015, 519 (7542), 237-241. https://doi.org/10.1038/nature14022.

(53) Subramanian, H.; Gupta, K.; Ali, H. Roles of Mas-Related G Protein-Coupled Receptor X2 on Mast Cell-Mediated Host Defense, Pseudoallergic Drug Reactions, and Chronic Inflammatory Diseases. Journal of Allergy and Clinical Immunology 2016, 138 (3), 700-710. https://doi.org/10.1016/j.jaci.2016.04.051.

(54) Green, D. P.; Limjunyawong, N.; Gour, N.; Pundir, P.; Dong, X. A Mast-Cell-Specific Receptor Mediates Neurogenic Inflammation and Pain. Neuron 2019, 101 (3), 412-420.e3. https://doi.org/10.1016/j.neuron.2019.01.012.

(55) Brown, T. D.; Whitehead, K. A.; Mitragotri, S. Materials for Oral Delivery of Proteins and Peptides. Nature Reviews Materials 2020, 5 (2), 127-148. https://doi.org/10.1038/s41578-0190156-6.

(56) Dan, N.; Samanta, K.; Almoazen, H. An Update on Pharmaceutical Strategies for Oral Delivery of Therapeutic Peptides and Proteins in Adults and Pediatrics. Children 2020, 7 (12), 307. https://doi.org/10.3390/children7120307.

(57) Zizzari, A. T.; Pliatsika, D.; Gall, F. M.; Fischer, T.; Riedl, R. New Perspectives in Oral Peptide Delivery. Drug Discovery Today 2021, 26 (4), 1097-1105. https://doi.org/10.1016/j.drudis.2021.01.020. 
(58) Amblard, M.; Fehrentz, J.-A.; Martinez, J.; Subra, G. Methods and Protocols of Modern Solid Phase Peptide Synthesis. Molecular Biotechnology 2006, 33, 239-254. https://doi.org/10.1385/MB:33:3:239.

(59) Johnson, B. A.; Blevins, R. A. NMR View: A Computer Program for the Visualization and Analysis of NMR Data. $J$ Biomol NMR 1994, 4 (5), 603-614. https://doi.org/10.1007/BF00404272.

(60) Wüthrich, K. NMR of Proteins and Nucleic acids; Wiley-Interscience: New York 1986.

(61) Case, D.; Betz, R.; Cerutti, D. S.; Cheatham, T.; Darden, T.; Duke, R.; Giese, T. J.; Gohlke, H.; Götz, A.; Homeyer, N.; Izadi, S.; Janowski, P.; Kaus, J.; Kovalenko, A.; Lee, T.-S.; LeGrand, S.; Li, P.; Lin, C.; Luchko, T.; Kollman, P. Amber 16, University of California, San Francisco.; 2016. https://doi.org/10.13140/RG.2.2.27958.70729.

(62) Koradi, R.; Billeter, M.; Wüthrich, K. MOLMOL: A Program for Display and Analysis of Macromolecular Structures. J Mol Graph 1996, 14 (1), 51-55. https://doi.org/10.1016/02637855(96)00009-4.

(63) Bowers, K. J.; Chow, D. E.; Xu, H.; Dror, R. O.; Eastwood, M. P.; Gregersen, B. A.; Klepeis, J. L.; Kolossvary, I.; Moraes, M. A.; Sacerdoti, F. D.; Salmon, J. K.; Shan, Y.; Shaw, D. E. Scalable Algorithms for Molecular Dynamics Simulations on Commodity Clusters. In SC '06: Proceedings of the 2006 ACM/IEEE Conference on Supercomputing; 2006; pp 43-43. https://doi.org/10.1109/SC.2006.54.

(64) Harder, E.; Damm, W.; Maple, J.; Wu, C.; Reboul, M.; Xiang, J. Y.; Wang, L.; Lupyan, D.; Dahlgren, M. K.; Knight, J. L.; Kaus, J. W.; Cerutti, D. S.; Krilov, G.; Jorgensen, W. L.; Abel, 
R.; Friesner, R. A. OPLS3: A Force Field Providing Broad Coverage of Drug-like Small Molecules and Proteins. $J$ Chem Theory Comput 2016, 12 (1), 281-296. https://doi.org/10.1021/acs.jctc.5b00864.

(65) Humphrey, W.; Dalke, A.; Schulten, K. VMD: Visual Molecular Dynamics. Journal of Molecular Graphics 1996, 14 (1), 33-38. https://doi.org/10.1016/0263-7855(96)00018-5.

(66) Ratkowsky, D. A.; Reedy, T. J. Choosing Near-Linear Parameters in the Four-Parameter Logistic Model for Radioligand and Related Assays. Biometrics 1986, 42 (3), 575-582. https://doi.org/10.2307/2531207. 
TABLE OF CONTENTS GRAPHIC

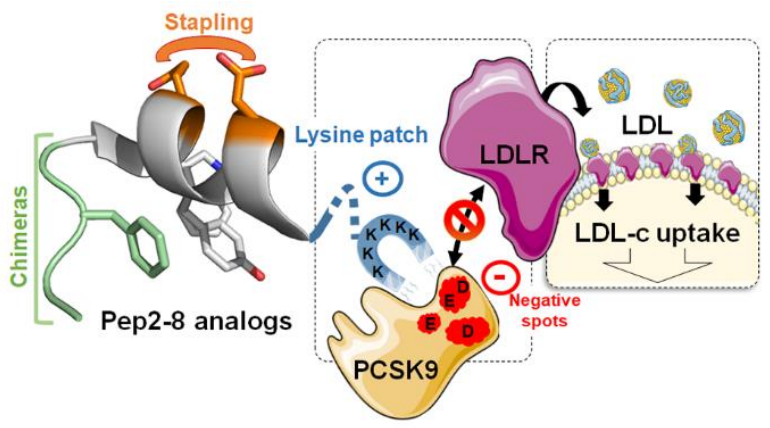

